\title{
Poliovirus receptor (PVR)-like protein cosignaling network: new opportunities for cancer immunotherapy
}

\author{
Baokang Wu', Chongli Zhong ${ }^{1}$, Qi Lang ${ }^{1}$, Zhiyun Liang ${ }^{1}$, Yizhou Zhang ${ }^{1}$, Xin Zhao', Yang Yu², Heming Zhang ${ }^{3}$, \\ Feng $\mathrm{Xu}^{1}$ and $\mathrm{Yu} \operatorname{Tian}^{1 *}$ (D)
}

\begin{abstract}
Immune checkpoint molecules, also known as cosignaling molecules, are pivotal cell-surface molecules that control immune cell responses by either promoting (costimulatory molecules) or inhibiting (coinhibitory molecules) a signal. These molecules have been studied for many years. The application of immune checkpoint drugs in the clinic provides hope for cancer patients. Recently, the poliovirus receptor (PVR)-like protein cosignaling network, which involves several immune checkpoint receptors, i.e., DNAM-1 (DNAX accessory molecule-1, CD226), TIGIT (Tcell immunoglobulin (lg) and immunoreceptor tyrosine-based inhibitory motif (ITIM)), CD96 (T cell activation, increased late expression (TACLILE)), and CD112R (PVRIG), which interact with their ligands CD155 (PVR/Necl-5), CD112 (PVRL2/nectin-2), CD111 (PVRL1/nectin-1), CD113 (PVRL3/nectin-3), and Nectin4, was discovered. As important components of the immune system, natural killer (NK) and T cells play a vital role in eliminating and killing foreign pathogens and abnormal cells in the body. Recently, increasing evidence has suggested that this novel cosignaling network axis costimulates and coinhibits NK and T cell activation to eliminate cancer cells after engaging with ligands, and this activity may be effectively targeted for cancer immunotherapy. In this article, we review recent advances in research on this novel cosignaling network. We also briefly outline the structure of this cosignaling network, the signaling cascades and mechanisms involved after receptors engage with ligands, and how this novel cosignaling network costimulates and coinhibits NK cell and T cell activation for cancer immunotherapy. Additionally, this review comprehensively summarizes the application of this new network in preclinical trials and clinical trials. This review provides a new immunotherapeutic strategy for cancer treatment.
\end{abstract}

Keywords: PVR, Cosignaling network, Receptor, Ligand, Cancer immunotherapy

\section{Background}

Immune checkpoint molecules, also known as cosignaling molecules, are pivotal cell-surface molecules controlling immune cell responses that either stimulate a signal (costimulatory molecules) or inhibit a signal (coinhibitory molecules) [1]. Checkpoint molecules mainly comprise members of the immunoglobulin superfamily and

\footnotetext{
*Correspondence: yu.tian@cmu.edu.cn

'Department of General Surgery, Shengjing Hospital of China Medical University, Shenyang 110004, Liaoning Province, China

Full list of author information is available at the end of the article
}

tumor necrosis factor/receptor superfamily [2]. Costimulatory molecules enhance the immune response by promoting a signal, whereas coinhibitory molecules attenuate the immune response by inhibiting a signal [3]. Natural killer (NK) cells and $\mathrm{T}$ cells are important components of the immune system, and their surface checkpoint molecules have been intensively studied. To date, several signaling pathways mediated by immune checkpoint molecules in immune cells have been reported to modulate the immune response while protecting against and killing virus-infected cells or malignant 
neoplastic cells. CTLA-4, as an immune checkpoint molecule, has been intensively investigated since its discovery [3-7]. Subsequently, PD-1, another immune checkpoint molecule, inhibits $\mathrm{T}$ cell cytotoxicity after binding with its ligands PD-L1/PD-L2 [8]. However, the immune checkpoint molecules mentioned above are secondary signals in the immune system that involve costimulatory or coinhibitory $\mathrm{T}$ cell cytotoxicity but not NK cell cytotoxicity. Similar to T cells, stimulatory and inhibitory receptors exist on the NK cell surface and guarantee that NK cells efficiently kill invading pathogens and infected or transformed cells but not normal cells by exerting cytotoxic effects after binding to their ligands [9].

Currently, researchers have developed drugs targeting checkpoint molecules for the clinical treatment of cancer. Ipilimumab is a monoclonal antibody (mAb) that enhances $\mathrm{T}$ cell activity by specifically targeting cytotoxic T-lymphocyte-associated protein 4 (CTLA-4) and was the first drug to be used in the clinic to significantly prolong survival in patients with advanced melanoma [3, 10]. Additionally, after this mAb drug was developed, two additional mAb drugs, pembrolizumab and nivolumab, were developed to treat cancers by selectively inhibiting the programmed cell death protein 1 (PD-1)/ programmed death-ligand 1 (PD-L1) inhibitory pathway. The cancer types that are responsive to PD-1 therapy with an objective clinical response include advanced melanoma, nonsmall-cell lung cancer, and kidney cancer [11]. The emergence of these mAbs is a milestone in cancer immunotherapy. However, clinical results indicate that many types of cancer, including pancreatic ductal adenocarcinoma (PDAC), colon cancer, prostate cancer, and ovarian cancer, do not respond or respond poorly to PD-1 blockade therapy [11].

Recently, poliovirus receptor (PVR)-like proteins, which are expressed on most immune cells, including NK cells and $T$ cells, were identified. These proteins include DNAX accessory molecule-1 (DNAM-1, CD226); T-cell immunoglobulin (Ig) and immunoreceptor tyrosine-based inhibitory motif (ITIM) (TIGIT); T cell activation, increased late expression (CD96, also identified as TACLILE); and CD112R (PVRIG). PVR-like proteins belong to a newly emerging immunoglobulin superfamily of proteins containing a PVR signature motif in the Ig variable-like (IgV) domain. This group of proteins initially attracted attention as adhesion proteins that mediate epithelial cell-cell contacts. The two main ligands, CD155 (PVR/Necl-5) and CD112 (PVRL2/nectin-2), can interact with these four receptors. In addition, other ligands, such as CD111 (PVRL1/nectin-1), CD113 (PVRL3/nectin-3), and Nectin4 (PVRL4), also interact with these receptors. In this review, we describe a new cosignaling network comprising four receptors and their ligands. This novel cosignaling pathway critically modulates the immune cell response and acts as a valuable checkpoint for cancer immunotherapy by regulating NK cells and $\mathrm{T}$ cells. However, the molecular and functional relationships among the components of the cosignaling pathway are unclear and need to be further researched.

\section{PVR like protein receptors DNAM-1}

DNAM1 is a $65-\mathrm{kD}$ immunoglobulin-like transmembrane glycoprotein consisting of an extracellular region with two IgV-like domains, a transmembrane region, a cytoplasmic region with an Ig tail-tyrosine (ITT), and four putative tyrosine residues and one serine residue that are phosphorylated [12, 13]. DNAM-1 is mainly expressed on the majority of monocytes, $\mathrm{T}$ cells, NK cells and platelets and on small subsets of B cells [12]. DNAM-1 is a costimulatory receptor that promotes intercellular adhesion, lymphocyte signaling, and lymphokine secretion and enhances NK cell and CTL cytotoxicity [12]. CD112/nectin2 and CD155/PVR have been identified as ligands of the DNAM1 receptor [14, 15], and the interaction between these ligands and receptors ensures NK or T cell-mediated lysis of tumor cells.

Although some studies have investigated the cellintrinsic signaling cascade, synergy with other NK receptors and cell-extrinsic mechanisms after DNAM-1 interacts with its ligands are described in the following section. However, further research is needed.

\section{Intrinsic signaling cascades and synergy with other NK receptors}

In NK cells, after DNAM-1 engages with its ligands CD112 and CD155 (Fig. 1), the $\operatorname{Ser}^{329}$ residue of DNAM-1 is phosphorylated by protein kinase C (PKC). Phosphorylated DNAM-1 subsequently crosslinks with leucocyte function-associated antigen-1 (LFA-1), resulting in lipid raft relocation and engagement with the cytoskeleton due to cooperation with the MAGUK homolog, large human discs, and the actin-binding protein 4.1G [16-18]. Then, the phosphorylation of the $\mathrm{Y}^{322}$ residue of DNAM-1 by Fyn src kinase is induced by LFA-1 [19]. It is now clear that DNAM-1 alone is not sufficient to trigger NK activation. Studies have shown that DNAM-1 synergizes with 2B4 to costimulate NK cells by phosphorylating the $\mathrm{Y}^{128}$ and $\mathrm{Y}^{113}$ residues of SLP-76 (SH2 domain-containing leukocyte phosphoprotein of $76 \mathrm{kDa}$ ). The dual phosphorylated form of SLP76 binds to two Vav1 molecules, which activates phospholipase $\mathrm{C} \gamma 2$ (PLC- $\gamma 2$ ), resulting in degranulation, cytokine secretion, and $\mathrm{Ca}^{2+}$ flux $[20,21]$. Additionally, DNAM-1 synergizes with $2 \mathrm{~B} 4$ to overcome the inhibition of Vav1 by the E3 ubiquitin ligase c-cbl [20]. 


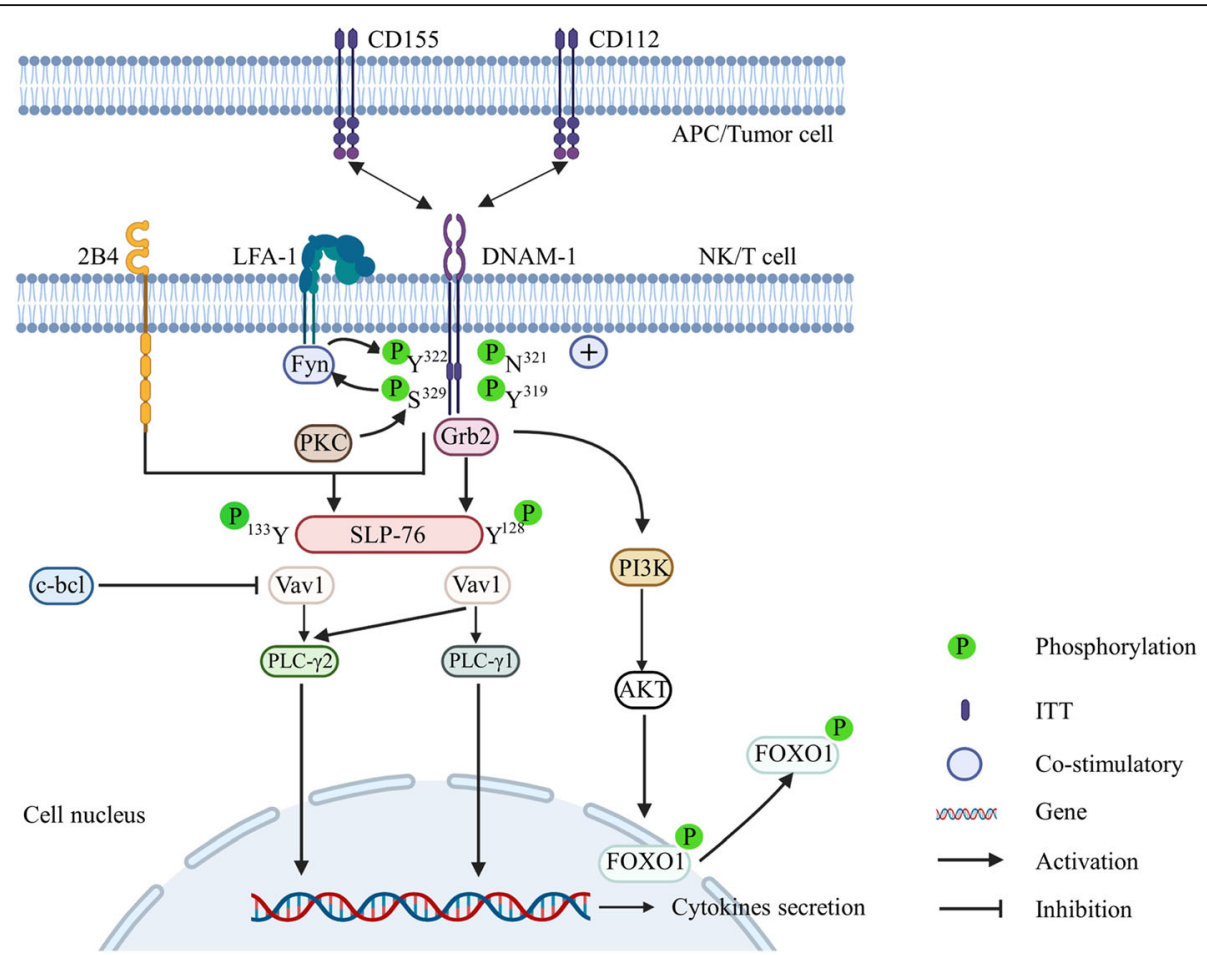

Fig. 1 Created with BioRender.com. The bidirectional arrow represents the interaction between DNAM-1 and its ligands. DNAM-1 exerts a costimulatory effect after engagement with its ligands CD155 and CD112. The intrinsic cell signaling cascade of DNAM-1 subsequently occurs in NK cells, and the sites of DNAM-1 $S^{329}$ and $Y^{322}$ are phosphorylated under the synergistic action of PKC and Fyn src kinase induced by LFA-1, resulting in dual SLP-76 phosphorylation at $Y^{128}$ and $Y^{113}$. This phosphorylated form of SLP-76 binds to Vav1 molecules to activate PLC- $\gamma 2$. Additionally, phosphorylated DNAM-1 recruits the adaptor Grb2, which leads to the activation of Vav-1, PI3K, and phospholipase C- $\gamma 1$ (PLC- $\gamma 1$ ). Both pathways lead to NK cell cytotoxicity changes

Recently, a study showed that upon recognition of its ligand, the asparagine residue at position $321\left(\mathrm{~N}^{321}\right)$ of DNAM-1 cooperates with the phosphorylated $\mathrm{Y}^{319}$ residue to recruit adaptor growth factor receptor-bound protein 2 (Grb2), leading to the activation of Vav-1, phosphatidylinositol 3 kinase (PI3K), and phospholipase C- $\gamma 1$ (PLC- $\gamma 1$ ) [13]. Furthermore, DNAM-1 promotes ERK and AKT activation. Activated AKT phosphorylates the downstream transcription factor FOXO1, a negative regulator of NK cell homing, late-stage maturation, and effector functions [22], and phosphorylated FOXO1 translocates from the nucleus to the cytoplasm, where it regulates natural killer cell antitumor responses [23].

\section{Cell-extrinsic signaling cascades}

In addition to being involved in intrinsic signaling cascades and synergizing with other NK receptors, DNAM1 exerts a costimulatory effect by disrupting Tregs (Fig. 2), thus exerting an immunosuppressive effect on the microenvironment in humans. In melanoma, a low TIGIT/DNAM-1 ratio in Tregs can attenuate their suppressive function and stability, resulting in a decreased number of Tregs in tumors [24]. Additionally, DNAM1+ TIGIT- Tregs are associated with a reduced Treg number and weak suppressive capacity after in vitro expansion while significantly increasing cytokine interleukin (IL)-10 production [25].

Preclinical and clinical trials of DNAM-1-related strategies Induction of the expression of DNAM-1 and its ligand represents a promising therapeutic strategy for cancer. An increasing number of studies have already reported that targeting DNAM-1 is a novel anticancer therapeutic strategy. Several preclinical (Table 1) and clinical trials (Table 2) of promising immune checkpoint-targeting strategies for cancer have been reported.

\section{Effect of DNAM-1 on NK cells in preclinical trials}

DNAM-1 can enhance NK cell cytotoxicity, which is involved in cancer cell recognition, regulation, and death. DNAM-1-induced NK cytotoxicity relies on the interaction of DNAM-1 with its ligands CD155 and CD112, which are highly expressed in cancer cells [51]. In vivo evidence has shown that DNAM-1 controls tumor metastasis, as recently demonstrated in mice lacking DNAM-1 [52, 53]. In coordination with the antitumor response, the overexpression of DNAM-1 ligands (DNAM-1Ls) on the cancer cell surface is induced to 


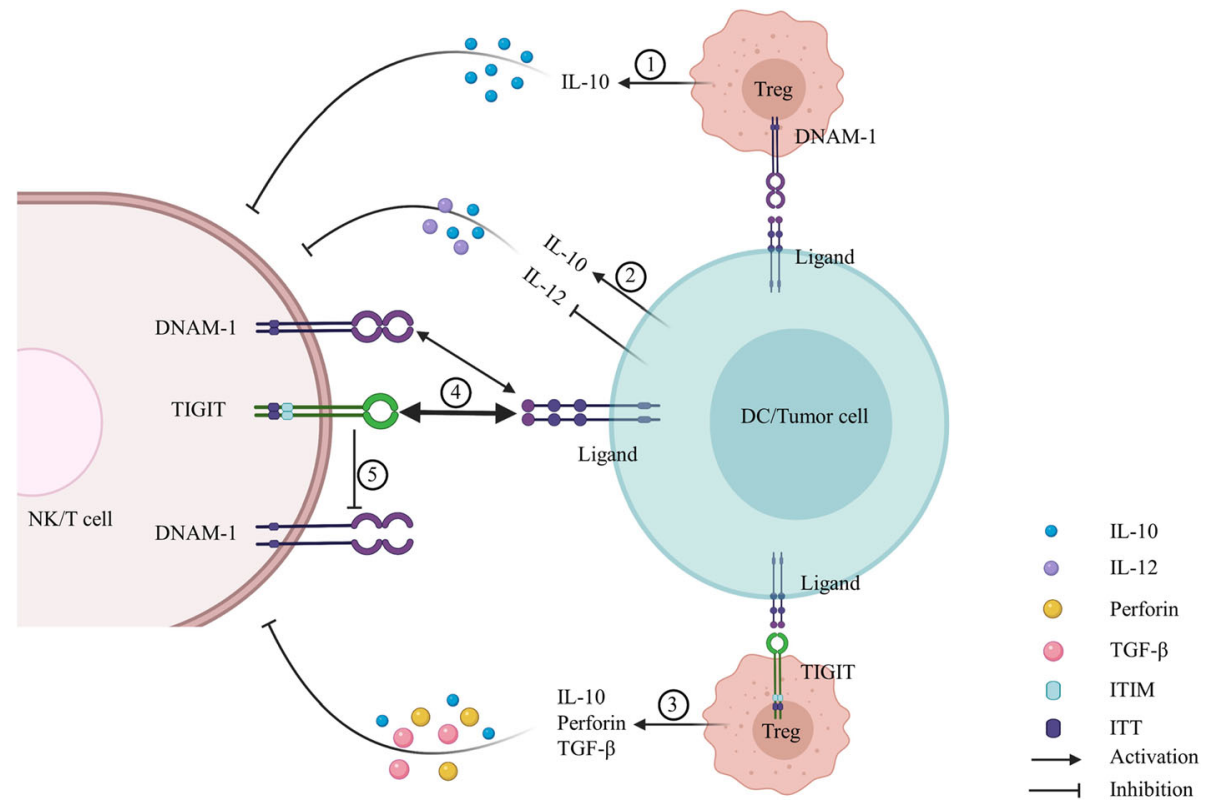

Fig. 2 Created with BioRender.com. Receptors DNAM-1 and TIGIT cell extrinsic mechanisms: (1) DNAM-1+ Tregs exert weak suppressive capacity with significantly increased cytokine IL-10 production. (2) TIGIT binding to its ligands expressed on dendritic cells (DCs) inhibits T cell activation by enhancing the production of IL-10 and reducing the production of IL-12 in DCs, which creates an immunosuppressive microenvironment. (3) TIGI T+ Tregs exhibit enhanced suppressive capacity by augmenting Treg suppression and stability with high expression of IL-10, perforin, and TGF- $\beta$. (4) The bidirectional arrow represents the interaction between receptors and their ligands. The thickness of the arrow represents affinity between receptors and their common ligand. TIGIT indirectly inhibits T cell activation by directly completing DNAM-1 binding to their common ligand. (5) TIGIT inhibits T cell activation by disrupting CD226 cis-homodimerization in human T cells

identify and eliminate NK cells $[26,54-60]$. A previous study showed that antibody-mediated masking of NK cell-activating receptors and costimulatory molecules, such as DNAM-1, natural cytotoxicity receptors (NCRs), and NK cell activating receptor natural-killer group 2, member D (NKG2D), frequently induces melanoma cell lysis after receptor-ligand engagement [61]. As mentioned above, PVR (CD155) and nectin2 (CD112) are ligands for DNAM-1. PVR-expressing neuroblastoma cells are efficiently killed by NK cells when engaging with DNAM-1. Blocking either DNAM-1 or PVR with an anti-DNAM-1 or anti-PVR antibody results in the significant inhibition of NK-mediated tumor cell lysis [26]. Similarly, NK-mediated lysis of tumor cells is enhanced after DNAM-1 (in NK cells) interacts with PVR or Nectin-2 (in target cells), whereas this effect is inhibited by treatment with a mAb targeting DNAM-1 or its receptor [15]. Similarly, soluble DNAM-1 (sDNAM-1) also inhibits the growth of cancer cell lines (K562 and HeLa cells) after binding CD155 or CD112 by enhancing NK cell cytotoxicity, and the inhibitory effect of DNAM1 is significantly attenuated after DNAM- 1 mAb blockade [62]. DNAM-1-mediated NK cell activation is altered by the microRNA miR-30c- $1^{*}$, which enhances NK cell cytotoxicity in human hepatoma cells by targeting the inhibitory transcription factor HMBOX1 and increases the expression of transmembrane tumor necrosis factor-alpha (mTNF- $\alpha$ ) [27]. After treatment with the anti-DNAM-1 mAb LeoA1, miR-30c-1* expression alters NK cell killing capacity [27]. The abovementioned studies demonstrated that anti-DNAM-1 mAbs alter NK cell cytotoxicity and are thus additional novel potential immunotherapeutic agents that inhibit tumors through DNAM-1 agonism. A few studies have demonstrated that DNAM-1 agonists increase DNAM-1 expression on the NK cell surface. Increased DNAM-1 improves NK cell cytotoxicity against melanoma cells and inhibits CNS autoimmunity in experimental autoimmune encephalomyelitis by interacting with the ligand CD155 in dendritic cells [28].

\section{Effect of DNAM-1 on T cells in preclinical trials}

DNAM-1 is expressed on T cells, and several recent preclinical studies have focused on cancer immunotherapy involving targeting DNAM-1 receptors on the $\mathrm{T}$ cell surface. DNAM-1 expression affects Treg function, and one study showed that DNAM-1- Tregs are more stable than DNAM-1+ Tregs during in vitro expansion [29]. Blocking the DNAM-1-CD155 interaction promotes Treg expansion and in vitro Treg production. Furthermore, an anti-DNAM-1 mAb prolongs skin allograft survival in a skin allograft model, 
Table 1 Preclinical trials in promising cancer target of PVR like receptors

\begin{tabular}{|c|c|c|c|c|c|}
\hline $\begin{array}{l}\text { PVR } \\
\text { like } \\
\text { protein }\end{array}$ & Treatment & $\begin{array}{l}\text { Immune } \\
\text { cells }\end{array}$ & Tumor & Results & Reference \\
\hline $\begin{array}{l}\text { DNAM- } \\
1\end{array}$ & $\begin{array}{l}\text { Anti-DMAN-1 } \\
\text { or anti-PVR } \\
\text { mAbs }\end{array}$ & NK & Neuroblastoma & $\begin{array}{l}\text { monoclonal antibody-mediated masking of either DNAM-1 (on NK } \\
\text { cells) or PVR (on neuroblasts) resulted in strong inhibition of tumor } \\
\text { cell lysis }\end{array}$ & {$[26]$} \\
\hline $\begin{array}{l}\text { DNAM- } \\
1\end{array}$ & $\begin{array}{l}\text { Anti-DMAN-1 } \\
\text { or anti-PVR } \\
\text { mAbs }\end{array}$ & NK & Tumor cell lines & $\begin{array}{l}\text { The ability of NK-mediated lysis of tumor cells mediated by DNAM-1 } \\
\text { engage with its ligands that was downregulated by mAb-mediated } \\
\text { masking of the receptor or its ligands }\end{array}$ & {$[15]$} \\
\hline $\begin{array}{l}\text { DNAM- } \\
1\end{array}$ & $\begin{array}{l}\text { anti-CD226 } \\
\text { mAb LeoA1 }\end{array}$ & NK & Hepatoma & $\begin{array}{l}\text { Crosslinking CD226 with the anti-CD226 mAb LeoA1 regulate miR- } \\
30 c-1 * \text { expression, which promoted NK cell cytotoxicity against hepa- } \\
\text { toma cells by targeting HMBOX1 }\end{array}$ & {$[27]$} \\
\hline $\begin{array}{l}\text { DNAM- } \\
1\end{array}$ & $\begin{array}{l}\text { DNAM-1 } \\
\text { agonist }\end{array}$ & NK & $\begin{array}{l}\text { Melanoma, experimental } \\
\text { autoimmune } \\
\text { encephalomyelitis }\end{array}$ & $\begin{array}{l}\text { DNAM-1 agonist could activate DNAM-1 modifies the bidirectional } \\
\text { crosstalk of NK cells with CD155 DC, which can suppress CNS auto- } \\
\text { immunity and strengthen tumor surveillance }\end{array}$ & {$[28]$} \\
\hline $\begin{array}{l}\text { DNAM- } \\
1\end{array}$ & $\begin{array}{l}\text { Anti-CD226 } \\
\text { mAb }\end{array}$ & Tregs & Allogeneic skin transplant & $\begin{array}{l}\text { CD226 mAb promoted Treg expansion, reduced inflammation and } \\
\text { prolonged allogeneic graft survival }\end{array}$ & [29] \\
\hline $\begin{array}{l}\text { DNAM- } \\
1\end{array}$ & $\begin{array}{l}\text { Anti-CD226 } \\
\text { mAb }\end{array}$ & $\gamma \delta \mathrm{T}$ & Hepatocellular carcinoma & $\begin{array}{l}\text { Anti-DNAM-1 mAb-mediated masking experiments that } \gamma \delta T \text { cells } \\
\text { cytotoxicity against HCC cells as well as IFN- } \gamma \text { production were } \\
\text { decreased }\end{array}$ & {$[30]$} \\
\hline $\begin{array}{l}\text { DNAM- } \\
1\end{array}$ & $\begin{array}{l}\text { CD226 agonist } \\
\text { antibody }\end{array}$ & $\mathrm{CD} 8+\mathrm{T}$ & $\begin{array}{l}\text { pancreatic ductal } \\
\text { adenocarcinoma }\end{array}$ & $\begin{array}{l}\text { CD226 agonist antibody-mediated activation of CD226 augments the } \\
\text { effect of TIGIT or PD-1 blockade on CD8 T-cell responses }\end{array}$ & {$[31]$} \\
\hline TIGIT & Anti-TIGIT & NK & Colon cancer & $\begin{array}{l}\text { Blockade of TIGIT prevented NK cell exhaustion and promoted NK } \\
\text { cell-dependent tumor immunity, enhanced therapy with antibody to } \\
\text { the PD-1 ligand PD-L1 }\end{array}$ & {$[32]$} \\
\hline TIGIT & Anti-TIGIT & NK & Ovarian cancer & $\begin{array}{l}\text { Blockade of TIGIT enhanced degranulation and interferon gamma } \\
\text { (IFN- } \gamma \text { ) production of NK cells in response to OC tumor cells }\end{array}$ & [33] \\
\hline TIGIT & Anti-TIGIT & $\mathrm{CD} 8+\mathrm{T}$ & Melanoma & $\begin{array}{l}\text { TIGIT and PD-1 blockade should be further explored to elicit potent } \\
\text { antitumor CD8+ T cell responses }\end{array}$ & [34] \\
\hline TIGIT & Anti-TIGIT & $\mathrm{CD} 8+\mathrm{T}$ & Gastric cancer & $\begin{array}{l}\text { Blockade TIGIT enhanced CD8 T cell activation and improved survival } \\
\text { in tumor bearing mice }\end{array}$ & [35] \\
\hline TIGIT & Anti-TIGIT & $\mathrm{CD} 8+\mathrm{T}$ & Multiple myeloma & $\begin{array}{l}\text { Blockade TIGIT by mAb increased the effector function of MM patient } \\
\text { CD8+ T cells and suppressed MM development }\end{array}$ & {$[36]$} \\
\hline TIGIT & Anti-TIGIT & $\mathrm{CD} 8+\mathrm{T}$ & Myeloma & $\begin{array}{l}\text { Immune checkpoint blockade using mAb against TIGIT significantly } \\
\text { restored CD } 8+\text { T exhaustion and prolonged myeloma control after } \\
\text { stem cell transplantation }\end{array}$ & {$[37]$} \\
\hline TIGIT & Anti-TIGIT & $\begin{array}{l}\text { CD8+ T, } \\
\text { Tregs }\end{array}$ & $\begin{array}{l}\text { Head and neck squamous } \\
\text { cell carcinoma }\end{array}$ & $\begin{array}{l}\text { Anti-TIGIT treatment significantly reverse T-cell exhaustion and reduce } \\
\text { the population of Tregs in vitro and in vivo }\end{array}$ & [38] \\
\hline TIGIT & Anti-TIGIT & $\begin{array}{l}\text { CD4+ T, } \\
\text { CD8+T, } \\
\text { Tregs }\end{array}$ & Multiple myeloma & $\begin{array}{l}\text { Anti-TIGIT mAb depleted FoxP3+ Tregs, increased proliferation of IFN- } \\
\text { Y-producing CD4+ T cells, and overcame the inhibition effect of } \\
\text { CD8+ T cell signaling and cell proliferation by PVR ligation }\end{array}$ & [39] \\
\hline TIGIT & Anti-TIGIT & 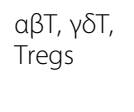 & Hematologic malignancies & $\begin{array}{l}\text { Anti-TIGIT mAbs could restore aßT-cell function, prevent CD155 medi- } \\
\text { ated inhibition of } \gamma \delta T \text { cells, depletion of Tregs, and direct killing of } \\
\text { tumor cells }\end{array}$ & {$[40]$} \\
\hline TIGIT & Anti-TIGIT & $\begin{array}{l}\text { Effector } T \text {, } \\
\text { Tregs }\end{array}$ & Glioblastoma & $\begin{array}{l}\text { TIGIT a checkpoint blockade increased effector T cell function and } \\
\text { downregulation of suppressive Tregs and TIDCs to enhance } \\
\text { antitumor immunity and survival in glioblastoma }\end{array}$ & [41] \\
\hline TIGIT & Anti-TIGIT & $\begin{array}{l}\text { CD4+ } \\
\text { Tregs }\end{array}$ & Ovarian cancer & Anti-TIGIT treatment reduced the proportion of CD4+ Tregs & [42] \\
\hline CD96 & Anti-CD96 & NK & $\begin{array}{l}\text { Melanoma lung } \\
\text { metastases }\end{array}$ & $\begin{array}{l}\text { Anti-CD96 enhances the NK cell IFN- } \gamma \text {-dependent effector function, } \\
\text { which significantly reduced experimental and spontaneous lung } \\
\text { metastases }\end{array}$ & [43] \\
\hline CD96 & Anti-CD96 & NK & Hepatocellular carcinoma & $\begin{array}{l}\text { Anti-CD96 antibody of blocking CD96 and its ligand CD155 } \\
\text { interaction, the human NK cell lines cytotoxicity was restored and } \\
\text { enhanced }\end{array}$ & [44] \\
\hline CD96 & Anti-CD96 & NK & Tumor metastases & CD96 targeted antibodies promote NK cell anti-tumor activity & [45] \\
\hline CD96 & Anti-CD96 & $\mathrm{CD} 8+\mathrm{T}$ & Anti-tumor & $\begin{array}{l}\text { Ab blockade on CD8+ T cells could eliminate IFN- } \gamma \text { and/or TNF-a pro- } \\
\text { duction, which associated with CD8+ T cell activation }\end{array}$ & [46] \\
\hline
\end{tabular}


Table 1 Preclinical trials in promising cancer target of PVR like receptors (Continued)

\begin{tabular}{|c|c|c|c|c|c|}
\hline $\begin{array}{l}\text { PVR } \\
\text { like } \\
\text { protein } \\
\end{array}$ & Treatment & $\begin{array}{l}\text { Immune } \\
\text { cells }\end{array}$ & Tumor & Results & Reference \\
\hline$\overline{C D 96}$ & Anti-CD96 & $\mathrm{CD} 8+\mathrm{T}$ & Melanoma & $\begin{array}{l}\text { Anti-CD96 therapy is effective to enhance CD8+ T activity and limit } \\
\text { tumor growth }\end{array}$ & [47] \\
\hline CD96 & Anti-CD96 & Th19 & Inflammatory diseases & $\begin{array}{l}\text { Blockade of CD96 significantly restored the expansion and } \\
\text { inflammatory properties of CD96 high } T \text { Th9 cells }\end{array}$ & [48] \\
\hline CD112R & Anti-CD112R & NK & Breast cancer & $\begin{array}{l}\text { Blockage CD112R could improve trastuzumab therapy for breast } \\
\text { cancer by enhancing NK cells activity }\end{array}$ & [49] \\
\hline CD112R & Anti-CD112R & $\mathrm{CD} 8+\mathrm{T}$ & $\begin{array}{l}\text { Melanoma, pancreatic } \\
\text { cancer }\end{array}$ & $\begin{array}{l}\text { Blockade of PVRIG increased CD8+ T-cell function, an effect enhanced } \\
\text { by combination with TIGIT or PD-1 blockade }\end{array}$ & [50] \\
\hline
\end{tabular}

$m A b$ monoclonal antibody, CNS central nervous system, HCC hepatocellular carcinoma, PD-1 programmed cell death 1, PD-L1 programmed cell death-ligand 1, TIDCs tumor-infiltrating dendritic cells

exhibiting novel therapeutic potential for allogeneic transplantation [29]. In addition to Tregs, DNAM-1expressing $\gamma \delta \mathrm{T}$ cells promote cancer cell lysis by engaging ligand nectin-like-5 (CD155) on hepatocellular carcinoma (HCC) cells. Combined mAb-mediated blockade shows that DNAM-1 and NKG2D synergistically affect the cytolytic activity of $\gamma \delta \mathrm{T}$ cells [30]. The abovementioned studies demonstrated that antiDNAM-1 mAbs alter $\mathrm{T}$ cell cytotoxicity and represent novel potential immunotherapeutic agents against tumors. DNAM-1 + CD8+ tumor-infiltrating T cells possess greater self-renewal ability and cytotoxicity, and DNAM-1 agonist antibody-mediated activation of DNAM-1 augments the effect of TIGIT blockade on CD8 T-cell responses and increases the number of DNAM-1 CD8 T cells, which improves responses to anti-TIGIT therapy for cancer immunotherapy [31].

\section{Clinical trials}

A phase aI/bI clinical trial of the DNAM-1 agonist LY3435151 alone or combined with pembrolizumab (anti-PD-1 mAb) is ongoing in patients with solid tumors, triple-negative breast cancer, gastric adenocarcinoma, head and neck squamous cell carcinoma, cervical carcinoma, high-grade serous ovarian carcinoma, undifferentiated pleomorphic sarcoma, and leiomyosarcoma (NCT04099277).

\section{TIGIT}

T-cell immunoglobulin and immunoreceptor tyrosinebased inhibitory motif (TIGIT) is a member of the immunoglobulin superfamily. It was first identified in 2009 as a coinhibitory receptor on immune cells [63]. TIGIT is a surface protein containing an extracellular IgV-like domain, a type 1 transmembrane domain, and an intracellular domain that contains an ITIM and an ITT-like motif [63]. As highlighted, ITT-like motifs play a crucial role in inhibiting signals. An increasing number of studies have demonstrated that TIGIT is expressed on NK cells, $\mathrm{T}$ cells, follicular helper $\mathrm{T}$ cells, and follicular regulatory $\mathrm{T}$ cells [63-67].

The ligands for TIGIT identified to date include CD112/nectin2 and CD155/PVR, which exhibits the highest affinity. As one of the members of the CD28 family [65], TIGIT shares the ligand CD155 with DNAM-1. The binding of CD155 to TIGIT suppresses T cell activation $[35,63]$. In addition to binding to CD155, TIGIT can bind to CD112, and both receptor-ligand interactions inhibit NK cytotoxicity directly through the ITIM motif, which inhibits the NK-mediated killing of tumor cells [64]. CD113 (Nectin-3 or PVRL3) was recently identified as a ligand for TIGIT, which suppresses $\mathrm{T}$ cell activity [63]. Nectin4 was originally described as belonging to the nectin family and mediates various cell functions, such as proliferation, differentiation, migration, and invasion $[68,69]$. A recent study revealed that Nectin4 is a novel ligand for TIGIT [70]. TIGIT suppresses immune responses mainly through three different mechanisms: direct signaling in cis, induction of ligand signaling in trans, and indirect signaling in competition with costimulatory receptors (Fig. 2).

\section{Direct signaling in cis}

To date, TIGIT direct signaling has been mainly investigated in NK cells (Fig. 3). The phosphorylated $\mathrm{Y}^{225}$ residue in the ITT-like motif of TIGIT binds to cytosolic adapter Grb2, which recruits SH2-containing inositol phosphatase-1 (SHIP1), subsequently resulting in the inhibition of the phosphoinositide 3-kinase (PI3K) and mitogen-activated protein kinase (MAPK) signaling pathways [71]. Moreover, the phosphorylation of the two downstream signaling factors AKT and ERK is inhibited, which decreases NK cell cytotoxic activity. In addition, phosphorylated $\mathrm{Y}^{225}$ in the ITT-like motif of TIGIT binds to adaptor $\beta$-arrestin 2 , which is involved in the modulation of immunity through the recruitment of SHIP1. Furthermore, phosphorylated TIGIT inhibits IFN- $\gamma$ production by impairing tumor necrosis factor 
Table 2 Clinical trials in promising cancer target of PVR like receptors

\begin{tabular}{|c|c|c|c|c|c|c|c|}
\hline $\begin{array}{l}\text { NCT } \\
\text { Number }\end{array}$ & Target & Agent & $\begin{array}{l}\text { Estimated } \\
\text { Enrollment }\end{array}$ & Phase & Condition & $\begin{array}{l}\text { Recruitment } \\
\text { Statue }\end{array}$ & $\begin{array}{l}\text { Estimated } \\
\text { Study } \\
\text { Completion } \\
\text { Date }\end{array}$ \\
\hline NCT04099277 & $\begin{array}{l}\text { DNAM- } \\
1\end{array}$ & LY3435151 & 2 & $\mathrm{al} / \mathrm{b} 1$ & $\begin{array}{l}\text { Solid Tumor, Triple-negative Breast Cancer, Gastric Adeno- } \\
\text { carcinoma, Head and Neck Squamous Cell Carcinoma, } \\
\text { Cervical Carcinoma, High Grade Serous Ovarian Carcin- } \\
\text { oma, Undifferentiated Pleomorphic Sarcoma, } \\
\text { Leiomyosarcoma }\end{array}$ & Terminated & May 5, 2020 \\
\hline NCT04656535 & TIGIT & AB154 & 46 & $0 / 1$ & Glioblastoma & $\begin{array}{l}\text { Not yet } \\
\text { recruiting }\end{array}$ & Jul, 2023 \\
\hline NCT03628677 & TIGIT & AB154 & 66 & । & Solid Tumor, Unspecified, Adult & Recruiting & Nov 10, 2021 \\
\hline NCT04262856 & TIGIT & AB154 & 150 & $\|$ & $\begin{array}{l}\text { Non Small Cell Lung Cancer, Nonsquamous Non Small } \\
\text { Cell Lung Cancer, Squamous Non Small Cell Lung Cancer, } \\
\text { Lung Cance }\end{array}$ & Recruiting & Jun 23, 2022 \\
\hline NCT04736173 & TIGIT & AB154 & 625 & III & $\begin{array}{l}\text { Non Small Cell Lung Cancer, Nonsquamous Non Small } \\
\text { Cell Lung Cancer, Squamous Non-small-cell Lung Cancer, } \\
\text { Lung Cancer }\end{array}$ & Recruiting & Jun 30, 2026 \\
\hline NCT03945253 & TIGIT & ASP8374 & 6 & । & Advanced Solid Tumors & Completed & Jun 12, 2020 \\
\hline NCT03260322 & TIGIT & ASP8374 & 169 & । & Advanced Solid Tumors & $\begin{array}{l}\text { Active, not } \\
\text { recruiting }\end{array}$ & Mar, 2022 \\
\hline NCT04693234 & TIGIT & BGB-A1217 & 167 & $\|$ & Cervical Cancer & $\begin{array}{l}\text { Not yet } \\
\text { recruiting }\end{array}$ & Mar 31, 2023 \\
\hline NCT04732494 & TIGIT & BGB-A1217 & 280 & $\|$ & Esophageal Squamous Cell Carcinoma & Recruiting & Mar, 2024 \\
\hline NCT04047862 & TIGIT & BGB-A1217 & 234 & । & Locally Advanced, Metastatic Solid Tumors & Recruiting & Aug, 2023 \\
\hline NCT04746924 & TIGIT & BGB-A1217 & 605 & III & Non-small Cell Lung Cancer & $\begin{array}{l}\text { Not yet } \\
\text { recruiting }\end{array}$ & Mar, 2025 \\
\hline NCT04150965 & TIGIT & $\begin{array}{l}\text { BMS- } \\
986207\end{array}$ & 104 & $|/| \mid$ & Multiple Myeloma, Relapsed Refractory Multiple Myeloma & Recruiting & Mar 30, 2022 \\
\hline NCT04354246 & TIGIT & COM902 & 45 & । & $\begin{array}{l}\text { Advanced Cancer, Ovarian Cancer; Lung Cancer, Colon } \\
\text { Cancer; Plasma Cell Neoplasm, Breast Cancer }\end{array}$ & Recruiting & Sep 30, 2022 \\
\hline NCT04353830 & TIGIT & IBI939 & 270 & $\mathrm{la} / \mathrm{lb}$ & Advanced Malignancies & Recruiting & Dec 31, 2023 \\
\hline NCT04672369 & TIGIT & IB|939 & 36 & । & Advanced Lung Cancer & $\begin{array}{l}\text { Not yet } \\
\text { recruiting }\end{array}$ & Oct 9, 2024 \\
\hline NCT04672356 & TIGIT & IB|939 & 20 & । & Advanced Lung Cancer & Recruiting & Nov 9, 2024 \\
\hline NCT04457778 & TIGIT & M6223 & 35 & । & Metastatic Solid Tumors & Recruiting & Sep 14, 2022 \\
\hline NCT04305054 & TIGIT & MK-7684 & 315 & $|/| \mid$ & Melanoma & Recruiting & Apr 3, 2030 \\
\hline NCT04305041 & TIGIT & MK-7684 & 200 & $|/| \mid$ & Melanoma & Recruiting & Apr 3, 2030 \\
\hline NCT04303169 & TIGIT & MK-7684 & 65 & $|/| \mid$ & Melanoma & Recruiting & Apr 3, 2030 \\
\hline NCT04761198 & TIGIT & MPH313 & 125 & $|/| \mid$ & $\begin{array}{l}\text { Solid Tumor, Adult Advanced Solid Tumor, Metastatic } \\
\text { Solid Tumor }\end{array}$ & Recruiting & Jun 30, 2023 \\
\hline NCT04543617 & TIGIT & MTIG7192A & 750 & III & Esophageal Squamous Cell Carcinoma & Recruiting & Dec 26, 2025 \\
\hline NCT04256421 & TIGIT & MTIG7192A & 470 & III & Small Cell Lung Cancer & Recruiting & Sep 29, 2023 \\
\hline NCT04294810 & TIGIT & MTIG7192A & 560 & III & Non-Small Cell Lung Cancer & Recruiting & Feb 21, 2025 \\
\hline NCT03708224 & TIGIT & MTIG7192A & 55 & $\|$ & $\begin{array}{l}\text { Cancer, Carcinoma, Squamous Cell Carcinoma, Head and } \\
\text { Neck Cancer }\end{array}$ & Recruiting & Nov 30, 2025 \\
\hline NCT03563716 & TIGIT & MTIG7192A & 135 & $\|$ & Non-small Cell Lung Cancer & $\begin{array}{l}\text { Active, not } \\
\text { recruiting }\end{array}$ & Oct 30, 2021 \\
\hline NCT03281369 & TIGIT & MTIG7192A & 410 & $|/| \mid$ & $\begin{array}{l}\text { Gastric Adenocarcinoma or Gastroesophageal Junction } \\
\text { Adenocarcinoma or Esophageal Carcinoma }\end{array}$ & Recruiting & Feb 11, 2023 \\
\hline NCT03119428 & TIGIT & $\begin{array}{l}\text { OMP-31 } \\
\text { M32 }\end{array}$ & 33 & । & Locally Advanced Cancer, Metastatic Cancer & Terminated & May 15, 2019 \\
\hline
\end{tabular}


Table 2 Clinical trials in promising cancer target of PVR like receptors (Continued)

\begin{tabular}{|c|c|c|c|c|c|c|c|}
\hline $\begin{array}{l}\text { NCT } \\
\text { Number }\end{array}$ & Target & Agent & $\begin{array}{l}\text { Estimated } \\
\text { Enrollment }\end{array}$ & Phase & Condition & $\begin{array}{l}\text { Recruitment } \\
\text { Statue }\end{array}$ & $\begin{array}{l}\text { Estimated } \\
\text { Study } \\
\text { Completion } \\
\text { Date }\end{array}$ \\
\hline NCT04254107 & TIGIT & SGN-TGT & 231 & I & $\begin{array}{l}\text { Non-small Cell Lung Cancer, Gastric Carcinoma, } \\
\text { Gastroesophageal Junction Carcinoma, Classical Hodgkin } \\
\text { Lymphoma, Diffuse Large B-cell Lymphoma, Peripheral T- } \\
\text { cell Lymphoma, Cutaneous Melanoma, Head and Neck } \\
\text { Squamous Cell Carcinoma; Bladder Cancer, Ovarian Can- } \\
\text { cer, Triple Negative Breast Cancer }\end{array}$ & Recruiting & Mar 31, 2023 \\
\hline NCT04570839 & CD112R & COM701 & 100 & $|/| \mid$ & Endometrial Neoplasms, Ovarian Cancer, solid Tumor & Recruiting & Dec, 2023 \\
\hline NCT03667716 & CD112R & COM701 & 140 & । & $\begin{array}{l}\text { Advanced Cancer, Ovarian Cancer, Breast Cancer, Lung } \\
\text { Cancer, Endometrial Cancer, Ovarian Neoplasm, Triple } \\
\text { Negative Breast Cancer, Lung Neoplasm, Neoplasm } \\
\text { Malignant, Colo-rectal Cancer }\end{array}$ & Recruiting & Dec, 2021 \\
\hline
\end{tabular}

(TNF) factor receptor (TNFR)-associated factor 6 (TRAF6) autoubiquitination and nuclear factor kappa B (NF-kB) activation [72]. Similarly, TIGIT exerts immunosuppressive effects on $\mathrm{CD} 8+\mathrm{T}$ cells by regulating signaling pathways, significantly decreasing the $\mathrm{p}-\mathrm{AKT} /$ $\mathrm{AKT}$ and $\mathrm{p}$-ERK/ERK ratios and increasing $\mathrm{p}-\mathrm{I} \kappa \mathrm{B} \alpha$ levels in HCC [73]. This action eventually results in decreased secretion of interferon- $\gamma$ (INF- $\gamma$ ), TNF- $\alpha$, and IL-17A and increased IL-10 secretion [73].

\section{Induction of ligand signaling in trans}

TIGIT exerts an immunosuppressive effect by inducing ligand signaling in trans (Fig. 2). TIGIT binds to its ligands expressed on dendritic cells (DCs). The TIGIT-Fc fusion protein inhibits $\mathrm{T}$ cell activation by enhancing the production of IL-10 and diminishing the production of IL-12p40 in DCs, creating an immunosuppressive microenvironment [63]. As mentioned previously, TIGIT is expressed on Treg cells, which are superior in suppressing

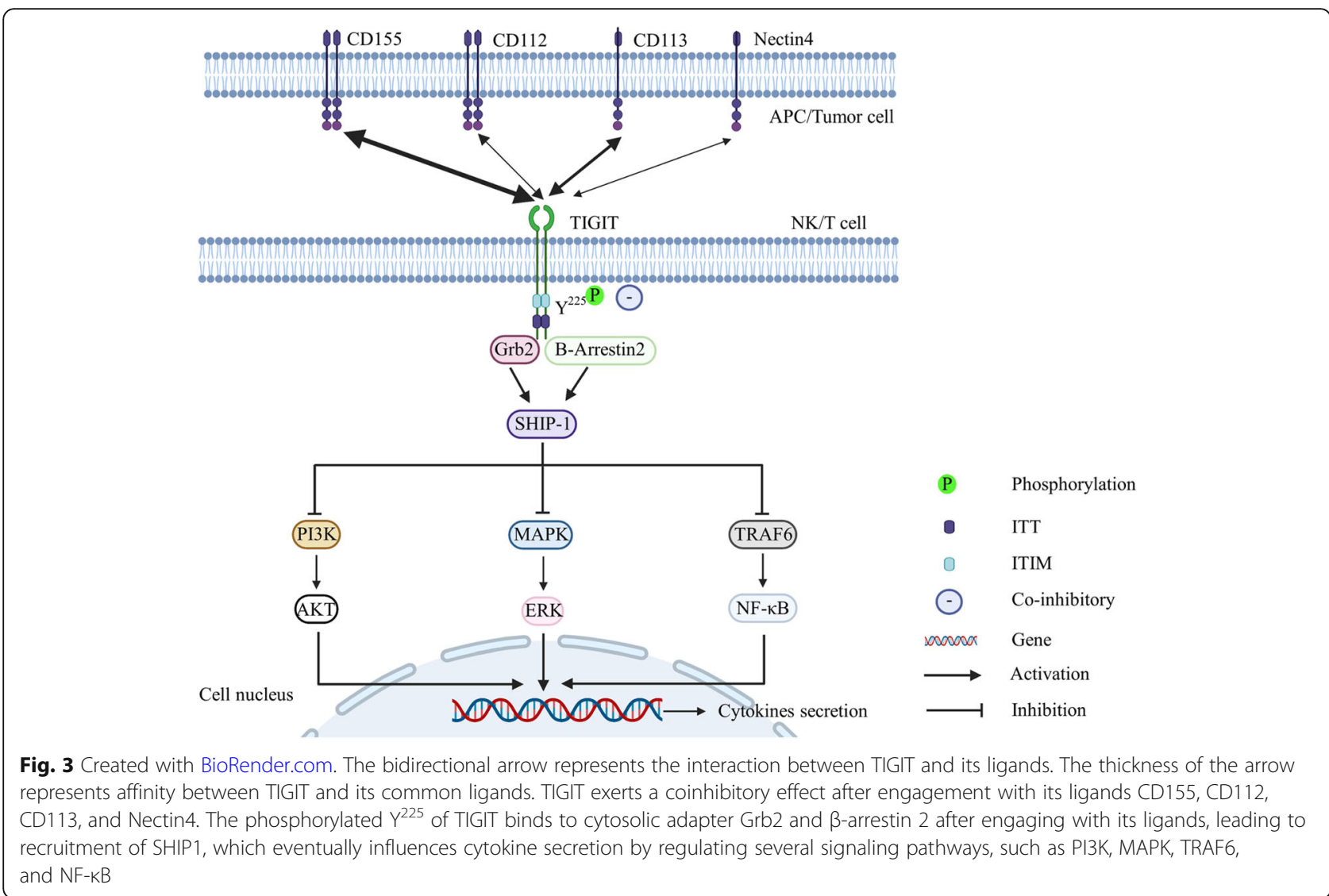


$\mathrm{T}$ cell activation. TIGIT+ Tregs exhibit better suppressive capacity than TIGIT- Tregs because they augment Treg suppression and stability [24, 25], which may be associated with high expression of IL-10, perforin, and TGF- $\beta$. Additionally, a study found that deletion of TIGIT in Tregs is effective in inhibiting tumor growth and enhancing CD8+ TIL cytotoxicity [74]. Thus, TIGIT may play a more dominant role in suppressing antitumor immunity via Tregs. However, Foxp3+ Treg cells increase the expression of the effector molecule fibrinogen-like protein 2 (Fgl2), which suppresses proinflammatory $\mathrm{T}$ helper 1 (Th1) and Th17 cell responses but not Th2 cell responses [75]. IL-4-expressing Th2 cells promote the differentiation of type 2 tumor-associated macrophages (TAM2), which inhibits T-cell responses by secreting IL-10 and TGF- $\beta$ and producing arginase-1 and indoleamine 2,3-dioxygenase (IDO) [76]. These cytokines and enzymes consume nutrients within the tumor microenvironment (TME), which regulates $\mathrm{T}$ cell activity.

\section{Indirect competition with costimulatory receptors}

PVR-like protein receptors exhibit different affinities for binding to different ligands. TIGIT has the highest affinity for CD155 followed by CD96 and DNAM-1 [63, 77]. Hence, TIGIT exerts an immunosuppressive effect on immune cells by abolishing DNAM-1-mediated costimulation. One study showed that TIGIT indirectly inhibits $\mathrm{T}$ cell activation by directly competing with DNAM-1 for binding to CD155 [78]. Additionally, TIGIT can disrupt DNAM-1 cis-homodimerization in human $\mathrm{T}$ cells [79]. Both studies suggest that TIGIT inhibits $\mathrm{T}$ cell activity by indirectly competing with costimulatory receptors (Fig. 2).

\section{Preclinical and clinical trials}

Evidence from preclinical (Table 1) and clinical trials (Table 2) supports the use of TIGIT-targeted immunotherapies. TIGIT has been shown to be a negative regulator of NK cell or $\mathrm{T}$ cell activity in preclinical trials. The number of recruiting, not yet recruiting, active but not recruiting and completed clinical trials assessing the safety and efficacy of a human anti-TIGIT monoclonal antibody for tumor treatment continues to increase.

\section{Effect of TIGIT on NK cells in preclinical trials}

Given the cytotoxicity of NK cells, increasing evidence has shown that TIGIT+ NK cell cytotoxicity is inhibited and that this inhibition is accompanied by decreased cytokine production. The cytotoxicity of human YTS NK cells transfected with TIGIT is inhibited [64]. The redirected killing ability of both human [64] and mouse primary NK cells [80] is decreased after TIGIT engages with its ligand CD155. TIGIT expression levels are related to the NK cell phenotype and functional heterogeneity [81]. Compared to NK cells with high expression of TIGIT, NK cells with low TIGIT expression exhibit an increased cytokine secretion capacity, degranulation activity and cytotoxicity [81]. In addition, MDSC-induced NK cell inhibition is associated with high expression of TIGIT and the TIGIT/CD155 interaction [82]. These data consistently show that high expression of the PVR receptor TIGIT exerts a coinhibitory effect on NK cells. Therefore, blockade of TIGIT or the TIGIT-ligand interaction represents a potentially promising cancer therapy. Studies have shown that blockade of TIGIT restores NK cell exhaustion and promotes NK cell-dependent tumor immunity, enhancing degranulation and IFN- $\gamma$ production in healthy donor CD56dim NK cells. This phenomenon is more apparent in combination with other checkpoint receptors $[32,33]$.

\section{Effect of TIGIT on T cells in preclinical trials}

Aberrant TIGIT expression results in tumor immune escape in the TME. Several groups have consistently reported that TIGIT is highly expressed on CD8+ TILs in many cancers, such as nonsmall cell lung cancer, colon cancer, melanoma [34, 79], and acute myelogenous leukemia [83]. Both melanoma and AML patients have an immunosuppressed microenvironment, largely due to low production of cytokines caused by high TIGIT expression [34, 83]. TIGIT expression is upregulated and DNAM-1 expression in CD8+ TILs is decreased in melanoma and AML patients, indicating the role of a TIGI T/DNAM-1 imbalance in tumor progression. These data consistently demonstrate that TIGIT negatively regulates $\mathrm{T}$-cell function. Knockdown of TIGIT in CD8+ T cells from AML patients reverses cytotoxic and proliferative capacity defects [83]. Moreover, blockade of TIGIT or an anti-TIGIT antibody enhances $\mathrm{T}$ cell activation and restores $\mathrm{CD} 8+\mathrm{T}$ exhaustion, enhancing antitumor activity in gastric cancer, colon cancer, myeloma, and head and neck squamous cell carcinoma [34-40]. In addition, TIGIT regulates Treg function. As mentioned above, Tregs are superior in suppressing $\mathrm{T}$ cell activation, and anti-TIGIT treatment reduces the proportion of CD4+ Tregs and inhibits the suppressive ability of Tregs [39-42], suggesting another pathway for cancer immunotherapy.

\section{Clinical trials}

Evidence from clinical trials supports the use of TIGIT-mediated immunotherapies. To date, twelve human anti-TIGIT monoclonal antibodies have been developed, i.e., AB154 (NCT04656535, NCT03628677, NCT04262856, NCT04736173), ASP8374 (NCT03945253, NCT03260322), BGB-A1217 (NCT04693234, NCT04732494, NCT04047862, NCT04746924), BMS- 
986207 (NCT04150965), COM902 (NCT04354246), IBI939 (NCT04353830, NCT04672369, NCT04672356), M6223 (NCT04457778), MK-7684 (NCT04305054, NCT04305041, NCT04303169), MPH313 (NCT04761198), MTIG7192A (NCT04543617, NCT04256421, NCT04294810, NCT03708224, NCT03563716, NCT03281369), OMP-31 M32 (NCT03119428), and SGN-TGT (NCT04254107). The safety and efficacy of these antibodies alone or combined with other immune checkpoint inhibitors, such as anti-PD-1, anti-PD-L1, anti-CTLA-4, anti-A2aR and anti-A2bR, are being studied in twenty-eight ongoing clinical trials in patients with human tumors; these trials are described in Table 2.

\section{CD96}

CD96, which was identified as TACTILE (T cell activation, increased late expression), is also a member of the Ig superfamily [84]. Human CD96 comprises one singlepass transmembrane region, three extracellular Ig-like domains/loops, and one cytoplasmic domain. These structural characteristics of CD96 enhance the complexity of its ligand interactions. Short cytoplasmic domains contain multiple binding sites with signal transduction capabilities, but the characteristics of intracellular signal transduction are less understood. The cytoplasmic domain of CD96 in both mice and humans contains a single putative ITIM motif, which is associated with its inhibitory function [85]. Moreover, the human CD96 cytoplasmic domain consists of a YXXM motif [86], which may activate receptors in certain contexts.

CD96 is expressed primarily on conventional $\alpha \beta$ and $\gamma \delta \mathrm{T}$ cells, NK cells, and a proportion of hematopoietic stem cells in humans [84, 87]. In mice, CD96 is expressed on $\alpha \beta$ and $\gamma \delta$ T cells, NK cells, and NKT cells $[52,88]$. However, CD96 is not expressed on B cells, DCs, resident or inflammatory monocytes, neutrophils, or granulocytes [52, 88-90]. Two ligands of CD96 have been identified: CD155 and CD111 (nectin-1). Similar to TIGIT and DNAM-1, CD96 interacts with CD155 to regulate NK cell and T cell functions. CD96 also interacts with CD111 (nectin-1) to regulate NK cell and T cell functions $[88,89,91]$. The costimulatory and coinhibitory effects of NK cells and T cells after CD96 engages with its ligands are complex and are described in the following section.

\section{CD96 signaling pathway}

CD96 regulates $\mathrm{T}$ cell function by inducing signaling pathways (Fig. 4). A region of the mouse CD96 intercellular domain binds with Grb2 and the $\mathrm{SH} 2$ and $\mathrm{SH} 3$ domains, which transduce signals [92, 93]. The mechanisms underlying the regulation of $\mathrm{T}$ cells by the

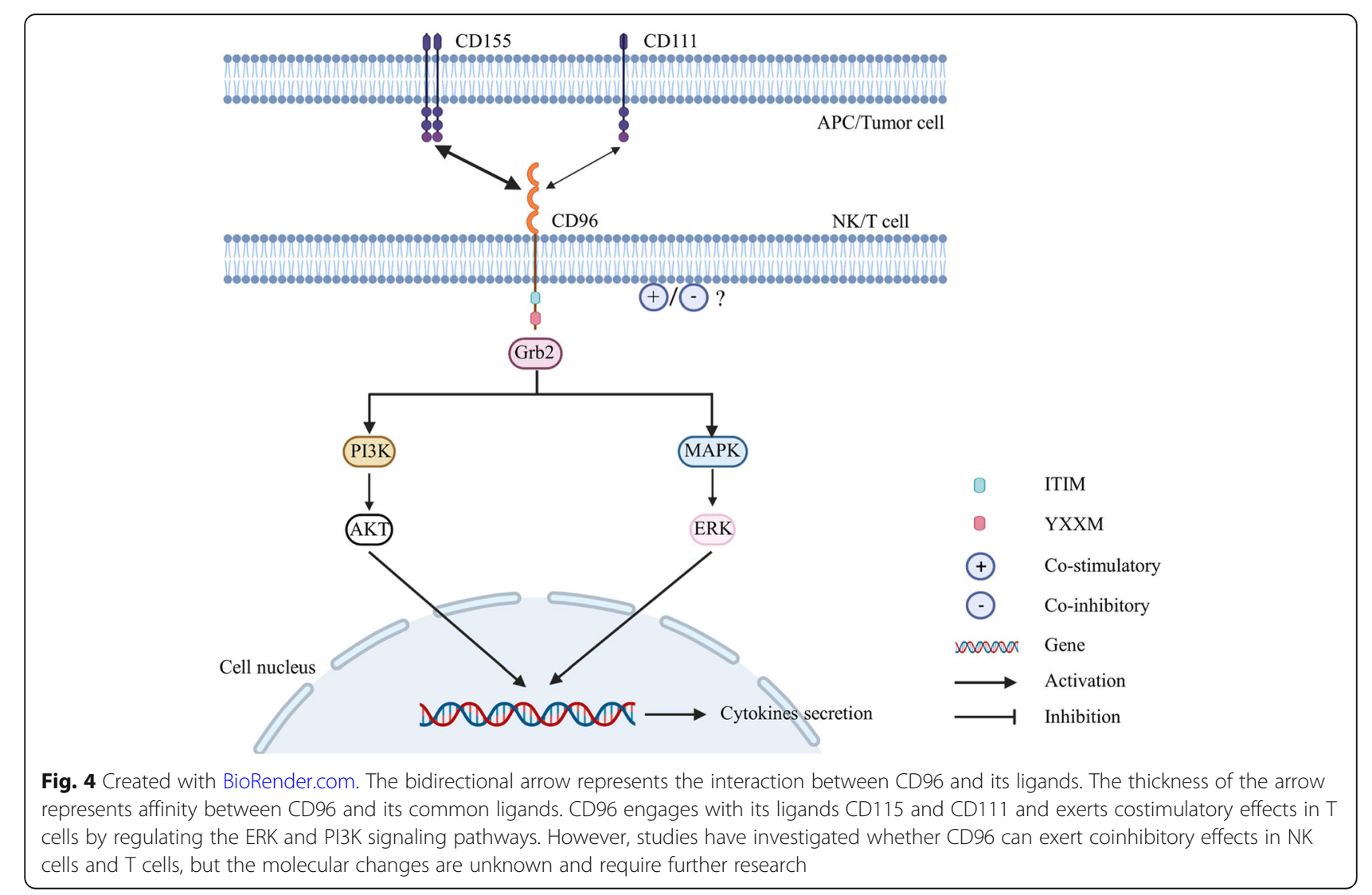


ERK signaling pathway have been investigated [94]. Beads coated with CD3/CD96 induce marked ERK phosphorylation. ERK is rapidly and transiently phosphorylated, and a dramatic reduction in signaling and differentiation is subsequently observed [46]. This finding indicates that CD96 functions as a costimulatory receptor in mouse CD8+ $\mathrm{T}$ cells by regulating the ERK signaling pathway. Human CD96 is similar to mouse CD96, and it is worth noting that human CD96 contains a YXXM motif. CD3/CD96 stimulation also enhances the phosphorylation of ERK in human CD8+ T cells [46]. Additionally, the YXXM motif binds the p85 subunit of PI3K [95], which phosphorylates and activates the downstream effector AKT. These data demonstrate that CD96 functions as a costimulatory receptor in human CD8+ T cells by regulating the PI3K/AKT signaling pathway [46].

\section{Preclinical and clinical trials of CD96-targeted therapies} Current preclinical data reveal that CD96 may have a coactivating or coinhibitory effect on human and/or mouse NK cells or T cells (Table 1) as described below. This apparent difference can be explained by the inherent differences in CD96 signaling between mice and humans as described previously; however, this effect has not been confirmed to date. Alternatively, these inconsistent results have been confirmed by several studies in mice and humans.

\section{Effect of CD96 on NK cells in preclinical trials}

CD96 negatively regulates human and mouse NK cell activity. CD96 attenuates NK cell cytotoxicity by competing with DNAM-1 for CD155 binding [52]. CD96(-/ -) mice display hyperinflammatory responses to the bacterial product lipopolysaccharide (LPS) and show resistance to carcinogenesis and experimental lung metastases. These results indicate that CD96 negatively controls cytokine responses by NK cells [52]. Hence, blocking CD96 is a potential cancer immunotherapy. An increasing number of preclinical trials have confirmed this hypothesis. Blocking CD96 or administering an antiCD96 antibody alone enhances NK cell function, which significantly reduces experimental and spontaneous lung metastases in mice. This effect is more apparent when these strategies are used in combination with antiCTLA4 antibodies, anti-PD-1/PD-L1 antibodies, and doxorubicin for cancer immunotherapy $[43,96]$. In human HCC samples, the number of CD96+ NK cells is significantly increased, and these cells are functionally exhausted and exhibit impaired IFN- $\gamma$ and TNF- $\alpha$ production, high gene expression of IL-10 and TGF- $\beta 1$, and low gene expression of T-bet, IL-15, perforin, and granzyme B [44]. In contrast, human NK cell cytotoxicity is restored and enhanced in the presence of an anti-CD96 antibody that blocks CD96 and its interaction with CD155 [44, 89]. Two anti-CD96 antibodies block the CD96-CD155 interaction (3.3 and 6A6), and one antibody (8B10) does not. Consistent with its inability to block CD96-CD155 interactions, 8B10 retains antitumor activity in CD155-deficient mice, whereas 3.3 and $6 \mathrm{~A} 6$ lose potency in CD155-deficient mice, suggesting that CD96-targeted antibodies promote NK cell antitumor activity without blocking the CD96-CD155 interaction [45].

\section{Effect of CD96 on T cells in preclinical trials}

CD96 regulates $\mathrm{T}$ cell activity rather than NK cell activity. However, the potential coactivating and coinhibitory effects of CD96 on human and/or mouse T cells are complicated. CD96 promotes human CD8+ T cell cytotoxic activity through the MEK-ERK pathway. Therefore, the absence of CD96 or Ab-mediated CD96 blockade on $\mathrm{CD} 8+\mathrm{T}$ cells abolishes IFN- $\gamma$ and/or TNF- $\alpha$ production, which is associated with $\mathrm{CD} 8+\mathrm{T}$ cell activation in in vivo models [46]. However, CD96-/-CD8+ T cells in mice promote tumor growth more than CD96-sufficient CD8+ T cells. In addition, anti-CD96 therapy is effective in enhancing $\mathrm{CD} 8+\mathrm{T}$ activity and limiting tumor growth and is more effective when administered in combination with blockade of a number of immune checkpoints, including PD-1, PD-L1, TIGIT, and CTLA-4 [47]. CD96low Th9 cells in (Rag1-/-) mice can cause severe weight loss, intestinal and colonic inflammation, and destruction of allogeneic skin grafts, showing expansion and tissue accumulation. In contrast, CD96high Th9 cells do not cause colitis and exhibit reduced expansion and migratory potential [48]. Interestingly, blockade of CD96 significantly restores the expansion and inflammatory properties of CD96high Th9 cells [48]. These results that CD96 plays an inhibitory role in suppressing IL-9-expressing Th9 cell activity, providing novel opportunities for the treatment of IL-9-associated inflammation, such as inflammatory bowel disease (IBD).

\section{Clinical trials}

Although the abovementioned preclinical trials have suggested that CD96 on NK cells and T cells may be potential targets for cancer immunotherapy, the expression levels of this immune checkpoint receptor differ on mouse and/or NK cells and T cells. In addition, CD96associated studies and clinical trials in human cancer patients are lacking. Thus, further studies of the potential of CD96 as a target molecule for cancer immunotherapy are needed.

\section{CD112R}

CD112R, previously named poliovirus receptor-related immunoglobulin domain-containing protein (PVRIG), is 
a novel member of the PVR-like cosignaling network. $\mathrm{CD} 112 \mathrm{R}$ is a $36-\mathrm{kD}$ transmembrane monomer composed of a single extracellular IgV domain, one transmembrane domain, and a long intracellular domain [97]. The human CD112R intracellular domain comprises two tyrosine residues, one of which is part of an ITIM-like motif and a potential site for phosphatases [98]. The extracellular domain sequences of human and mouse CD112R exhibit $\sim 65.3 \%$ homology. In addition, phylogenetic tree analysis of the first IgV of the PVR family revealed that CD112R is closely related to PVR-like proteins [97].

$\mathrm{CD} 112 \mathrm{R}$ is expressed at low and variable levels on the surface of freshly isolated T-cells and NK cells (predominantly on CD8+ T-cells, which are mainly memory/effector but not naïve cells) and on both $\mathrm{CD} 16+$ and CD16- NK cells in humans. CD112R is not detected in B-cells (CD19+), naïve (CD45RA + CCR7+) or helper (CD4+) T-cells, monocytes (CD14+), or neutrophils $(\mathrm{CD} 66 \mathrm{~b}+)$ at the protein level. Moreover, CD112R is not detected on DCs in humans. CD112R expression on the surface of $\mathrm{T}$ cells is further upregulated by treatment with anti-CD3 and anti-CD28 antibodies [97]. CD112R strongly interacts with CD112/Nectin2 and acts as a coinhibitory receptor that suppresses receptor-mediated signals and inhibits immune cell proliferation. CD112R and DNAM-1 share a common binding site on CD112. CD112R competes with DNAM-1 for binding to CD112 on $\mathrm{T}$ cells and mediates an inhibitory signal. CD112R is the receptor for CD112 with the highest affinity in both humans and mice and mediates the interaction of immune cells with DCs and tumor cells [97].

\section{CD112R signaling pathway}

The $\mathrm{Y}^{233}$ residue of the ITIM-like motif in the CD112R intracellular domain is phosphorylated by tyrosine phosphatases to mediate signal transduction [97] (Fig. 5). This finding was confirmed in the CD112Rhigh leukemia $\mathrm{T}$ cell line Molt4. The results showed that SHIP is strongly associated with CD112R in untreated Molt4 cells, and this interaction further increases upon pervanadate treatment. In addition, SHP-1 and SHP-2 are weakly associated with CD112R in untreated Molt4 cells, but pervanadate treatment further enhances these associations [97]. All these results suggest that CD112R transduces signals by recruiting tyrosine phosphatases. Additionally, this study suggested that CD112R

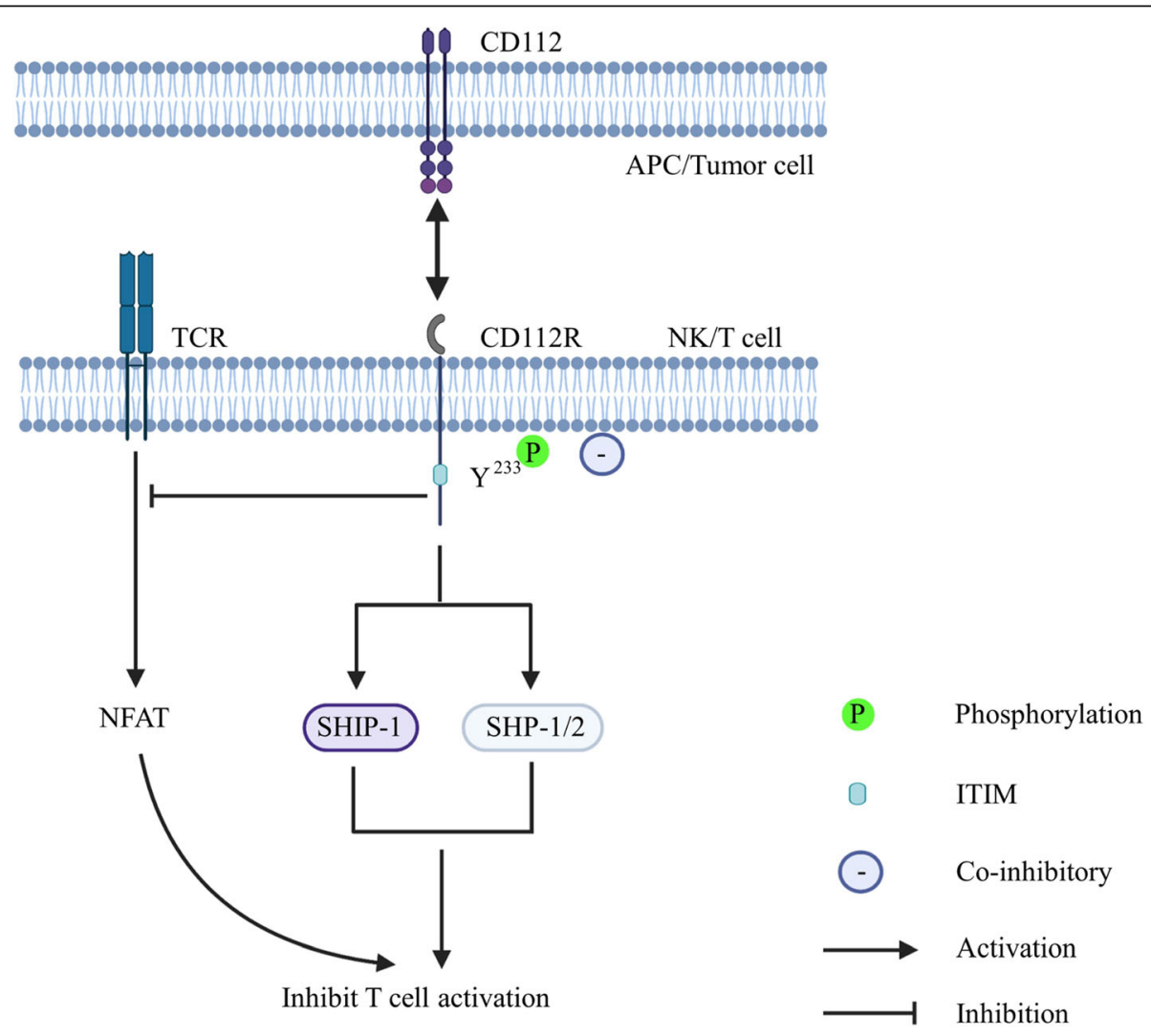

Fig. 5 Created with BioRender.com. The bidirectional arrow represents the interaction between CD112R and its ligand. CD112R engages with its ligand, and the phosphorylated $Y^{233}$ residue of the ITIM-like motif recruits SHIP-1 and SHP1/2 to mediate signal transduction, leading to a decrease in T cell cytotoxicity. Additionally, CD112R potentially represents a new coinhibitory receptor that suppresses T cell receptor-mediated NFAT activation 
potentially represents a new coinhibitory receptor that suppresses $\mathrm{T}$ cell receptor-mediated NFAT activation.

\section{Effect of CD112R on NK cells in preclinical trials}

Few studies on cancer immunotherapies have focused on targeting CD112R PVR-like checkpoint proteins. CD112R is expressed on human NK cells, although its function in this cell type is unclear. The number of human NK cells expressing the PVR receptor CD112R or TIGIT (CD56+) decreases with decreased IFN- $\gamma$ production in CD112-positive breast cancer, indicating that CD112R engagement with the ligand CD112 suppresses NK cell cytotoxicity [49]. Xu and coworkers showed that blockade of TIGIT and CD112R separately or together improves the effect of trastuzumab on breast cancer by enhancing NK cell activity [49].

\section{Effect of CD112R on T cells in preclinical trials}

Interestingly, instead of mediating NK cells, CD112R plays a vital role in $\mathrm{T}$-cell-mediated cancer immunity. CD112R is a distinct inhibitory signaling molecule on human $\mathrm{CD} 8+\mathrm{T}$ cells that decreases IFN $-\gamma$ production [50]. COM701 is a humanized anti-CD112R hingestabilized IgG4 that binds to human CD112R and disrupts the CD112R-CD112 interaction, which enhances T-cell function. This effect is enhanced by TIGIT or PD-1 blockade in Mel-624 cells and Panc.05.04 cells [50]. Furthermore, COM701 + nivolumab (anti-PD-1) or COM701 alone result in better outcomes in patients with advanced solid tumors in a phase I clinical trial [50]. CD112R is a novel member of the PVR-like protein cosignaling network. Research on the interactions of CD112R with other poliovirus-like ligands is lacking, and these interactions need to be studied further.

\section{Clinical trials}

One human anti-CD112R monoclonal antibody, COM701, has entered clinical trials. When combined with blockade of CD112R and TIGIT, PD-1 exerts a more powerful antitumor effect in preclinical models. Thus, two clinical trials are being performed to evaluate the safety and efficacy of combination anti-TIGIT (BMS-986207) and anti-PD-1 (Opdivo, Nivolumab) therapy as well as anti-CD112R monotherapy. These trials are ongoing in patients with endometrial neoplasms, ovarian cancer, solid tumors (NCT04570839), advanced cancer, ovarian cancer, breast cancer, lung cancer, endometrial cancer, ovarian neoplasm, triple-negative breast cancer, and colorectal cancer (NCT03667716).

\section{Conclusion}

In recent years, immunotherapy has represented one of the most promising therapeutic methods for cancer therapy and has attracted a considerable amount of attention. Immunotherapy utilizes the body's immune system to kill and eliminate infected and transformed cells by enhancing NK and T cell activities and is safe and highly effective. Although the costimulatory and coinhibitory mechanisms of NK and T cells after receptors in the PVR-like protein cosignaling network engage with their ligand have been studied, the detailed intracellular signaling mechanisms are unclear and need to be elucidated. Recently, anti-PD-1 mAbs were approved by the Food and Drug Administration (FDA) for the treatment of many cancers. The challenge in the future will be to develop mAbs targeting molecules in this cosignaling network to treat cancers. Based on the abovementioned data, we know that the efficacy of strategies targeting these cosignaling network receptors is increased when used in combination with other existing immune checkpoint blockade therapies, such as antiCTLA-4 or anti-PD-1 mAbs, to treat cancer. The next challenge we face is the development of combination therapies involving mAbs targeting molecules in this novel cosignaling network and other unknown immune checkpoints for cancer treatment. More importantly, clinical results indicate that many cancers, such as kidney, gallbladder, or bile duct malignant tumors, do not respond or respond poorly to immune checkpoint blockade therapy. How numerous innate receptors regulate NK cell and $T$ cell responsiveness spatially and temporally is unclear and therefore should be investigated to identify other receptors and their ligands that share the same structure.

\section{Abbreviations \\ PVR: Poliovirus receptor; DNAM-1: DNAX accessory molecule-1; TIGIT: T-cell immunoglobulin and immunoreceptor tyrosine-based inhibitory motif; NK: Natural killer; CTLA-4: Cytotoxic T lymphocyte antigen-4; PD- 1: Programmed cell death 1; PD-L1: Programmed cell death-ligand 1; Ig: Immunoglobulin; ITIM: Immunoreceptor tyrosine-based inhibitory motif; IgV: Ig variable; mAb: Monoclonal antibody; CNS: Central nervous system; HCC: Hepatocellular carcinoma; ITT: Ig tail-tyrosine; PKC: Protein kinase C; LFA-1: Leucocyte function-associated antigen-1; SLP-76: SH2 domain- containing leukocyte phosphoprotein of 76 kDa; Grb2: Growth factor receptor-bound protein 2; PLC- $\gamma 2$ : phospholipase C $\gamma 2$; PLC- \\ ү1: phospholipase CY1; PI3K: Phosphatidylinositol 3'kinase; DNAM-1Ls: DNAM- \\ 1 ligands; NKG2D: NK cell activating receptor natural-killer group 2, member D; SHIP1: SH2-containing inositol phosphatase-1; MAPK: Mitogen-activated protein kinase; INF- $\gamma$ : Interferon- - ; TNF-a: Tumor necrosis factor-alpha; TGF- $\beta$ : Transforming growth factor-beta}

\section{Acknowledgements}

Not applicable.

\section{Authors' contributions}

$B K W, C L Z, Q L, Z Y L, Y Z Z$, and ZZ drafted the manuscript; $Y Y$ and $H M Z$ completed the figures and tables; $Y T$ and FX managed the article design, reviewed the manuscript; YT provided funding support. All authors have read and approved the final manuscript.

\section{Funding}

This work supported in part by the Natural Science Foundation of China (81974377) and the Scientific Research Project of Education Department of Liaoning Province (JC2019017) 345 Talent Project (2019-2021). 


\section{Availability of data and materials}

Not applicable.

\section{Declarations}

Ethics approval and consent to participate

Not applicable.

\section{Consent for publication}

Not applicable.

\section{Competing interests}

The authors declare that they have no competing interests.

\section{Author details}

${ }^{1}$ Department of General Surgery, Shengjing Hospital of China Medical University, Shenyang 110004, Liaoning Province, China. ${ }^{2}$ Department of Surgery, Jinzhou Medical University, Jinzhou 121001, Liaoning Province, China. ${ }^{3}$ Department of College of Medical and Biological Information Engineering, Northeastern University, Shenyang 110819, Liaoning Province, China.

Received: 26 April 2021 Accepted: 10 August 2021

Published online: 25 August 2021

\section{References}

1. Zhu Y, Yao S, Chen L. Cell surface signaling molecules in the control of immune responses: a tide model. Immunity. 2011;34(4):466-78. https://doi. org/10.1016/j.immuni.2011.04.008

2. Chen $\mathrm{L}$, Flies DB. Molecular mechanisms of $\mathrm{T}$ cell co-stimulation and coinhibition. Nat Rev Immunol. 2013;13(4):227-42. https://doi.org/10.1038/ nri3405

3. Zang $X$, Allison JP. The B7 family and cancer therapy: costimulation and coinhibition. Clin Cancer Res. 2007;13(18):5271-9. https://doi.org/10.1158/1 078-0432.CCR-07-1030

4. Gimmi CD, Freeman GJ, Gribben JG, Sugita K, Freedman AS, Morimoto C, et al. B-cell surface antigen B7 provides a costimulatory signal that induces T cells to proliferate and secrete interleukin 2. Proc Natl Acad Sci U S A. 1991;88(15):6575-9. https://doi.org/10.1073/pnas.88.15.6575.

5. Harding FA, McArthur JG, Gross JA, Raulet DH, Allison JP. CD28-mediated signalling co-stimulates murine $T$ cells and prevents induction of anergy in T-cell clones. Nature. 1992;356(6370):607-9. https://doi.org/10.1038/356607a 0.

6. Koulova L, Clark EA, Shu G, Dupont B. The CD28 ligand B7/BB1 provides costimulatory signal for alloactivation of CD4+ T cells. J Exp Med. 1991; 173(3):759-62. https://doi.org/10.1084/jem.173.3.759.

7. Rudd CE, Taylor A, Schneider H. CD28 and CTLA-4 coreceptor expression and signal transduction. Immunol Rev. 2009;229(1):12-26. https://doi.org/1 0.1111/j.1600-065X.2009.00770.X.

8. Freeman GJ, Long AJ, Iwai Y, Bourque K, Chernova T, Nishimura H, et al. Engagement of the PD-1 immunoinhibitory receptor by a novel B7 family member leads to negative regulation of lymphocyte activation. J Exp Med. 2000;192(7):1027-34. https://doi.org/10.1084/jem.192.7.1027.

9. Lanier LL. Up on the tightrope: natural killer cell activation and inhibition. Nat Immunol. 2008;9(5):495-502. https://doi.org/10.1038/ni1581.

10. Chodon T, Koya RC, Odunsi K. Active immunotherapy of Cancer. Immunol Investig. 2015;44(8):817-36. https://doi.org/10.3109/08820139.2015.1096684

11. Topalian SL, Hodi FS, Brahmer JR, Gettinger SN, Smith DC, McDermott DF, et al. Safety, activity, and immune correlates of anti-PD-1 antibody in cancer. N Engl J Med. 2012;366(26):2443-54. https://doi.org/10.1056/NEJMoa12 00690.

12. Shibuya A, Campbell D, Hannum C, Yssel H, Franz-Bacon K, McClanahan T, et al. DNAM-1, a novel adhesion molecule involved in the cytolytic function of T lymphocytes. Immunity. 1996;4(6):573-81. https://doi.org/10.1016/S1 074-7613(00)70060-4

13. Zhang Z, Wu N, Lu Y, Davidson D, Colonna M, Veillette A. DNAM-1 controls NK cell activation via an ITT-like motif. J Exp Med. 2015;212(12):2165-82. https://doi.org/10.1084/jem.20150792.

14. Bottino C, Castriconi R, Pende D, Rivera P, Nanni M, Carnemolla B, et al. Identification of PVR (CD155) and Nectin-2 (CD112) as cell surface ligands for the human DNAM-1 (CD226) activating molecule. J Exp Med. 2003; 198(4):557-67. https://doi.org/10.1084/jem.20030788.

15. Pende D, Bottino C, Castriconi R, Cantoni C, Marcenaro S, Rivera P, et al. PVR (CD155) and Nectin-2 (CD112) as ligands of the human DNAM-1 (CD226) activating receptor: involvement in tumor cell lysis. Mol Immunol. 2005; 42(4):463-9. https://doi.org/10.1016/j.molimm.2004.07.028.

16. Shibuya A, Lanier $L L$, Phillips $J H$. Protein kinase $C$ is involved in the regulation of both signaling and adhesion mediated by DNAX accessory molecule-1 receptor. J Immunol. 1998;161:1671-6.

17. Ralston KJ, Hird SL, Zhang X, Scott JL, Jin B, Thorne RF, et al. The LFA-1associated molecule PTA-1 (CD226) on T cells forms a dynamic molecular complex with protein 4.1G and human discs large. J Biol Chem. 2004; 279(32):33816-28. https://doi.org/10.1074/jbc.M401040200.

18. Enqvist M, Ask EH, Forslund E, Carlsten M, Abrahamsen G, Béziat V, et al. Coordinated expression of DNAM-1 and LFA-1 in educated NK cells. J Immunol. 2015;194(9):4518-27. https://doi.org/10.4049/jimmunol.1401972.

19. Shibuya K, Shirakawa J, Kameyama T, Honda S, Tahara-Hanaoka S, Miyamoto A, et al. CD226 (DNAM-1) is involved in lymphocyte function-associated antigen 1 costimulatory signal for naive $T$ cell differentiation and proliferation. J Exp Med. 2003;198(12):1829-39. https://doi.org/10.1084/jem.2 0030958

20. Kim HS, Das A, Gross CC, Bryceson YT, Long EO. Synergistic signals for natural cytotoxicity are required to overcome inhibition by c-Cbl ubiquitin ligase. Immunity. 2010;32(2):175-86. https://doi.org/10.1016/j.immuni.2010. 02.004 .

21. Kim HS, Long EO. Complementary phosphorylation sites in the adaptor protein SLP-76 promote synergistic activation of natural killer cells. Sci Signal. 2012;5:ra49.

22. Deng $Y$, Kerdiles $Y$, Chu J, Yuan S, Wang Y, Chen $X$, et al. Transcription factor Foxo1 is a negative regulator of natural killer cell maturation and function. Immunity. 2015;42(3):457-70. https://doi.org/10.1016/j.immuni.2 015.02 .006

23. Du X, de Almeida P, Manieri N, de Almeida ND, Wu TD, Harden Bowles K, et al. CD226 regulates natural killer cell antitumor responses via phosphorylation-mediated inactivation of transcription factor FOXO1. Proc Natl Acad Sci U S A. 2018:115(50):E11731-e11740. https://doi.org/10.1073/ pnas.1814052115

24. Fourcade J, Sun Z, Chauvin JM, Ka M, Davar D, Pagliano O, et al. CD226 opposes TIGIT to disrupt Tregs in melanoma. JCI Insight. 2018;3(14). https:// doi.org/10.1172/jci.insight.121157.

25. Fuhrman CA, Yeh WI, Seay HR, Saikumar Lakshmi P, Chopra G, Zhang L, et al. Divergent phenotypes of human regulatory $T$ cells expressing the receptors TIGIT and CD226. J Immunol. 2015;195(1):145-55. https://doi.org/1 0.4049/jimmunol.1402381.

26. Castriconi R, Dondero A, Corrias MV, Lanino E, Pende D, Moretta L, et al. Natural killer cell-mediated killing of freshly isolated neuroblastoma cells: critical role of DNAX accessory molecule-1-poliovirus receptor interaction. Cancer Res. 2004;64(24):9180-4. https://doi.org/10.1158/0008-5472.CAN-04-2 682.

27. Gong J, Liu R, Zhuang R, Zhang Y, Fang L, Xu Z, et al. miR-30c-1* promotes natural killer cell cytotoxicity against human hepatoma cells by targeting the transcription factor HMBOX1. Cancer Sci. 2012;103(4):645-52. https://doi. org/10.1111/j.1349-7006.2012.02207.x.

28. Ott M, Avendaño-Guzmán E, Ullrich E, Dreyer C, Strauss J, Harden M, et al. Laquinimod, a prototypic quinoline-3-carboxamide and aryl hydrocarbon receptor agonist, utilizes a CD155-mediated natural killer/dendritic cell interaction to suppress CNS autoimmunity. J Neuroinflammation. 2019;16(1): 49. https://doi.org/10.1186/s12974-019-1437-0.

29. Liu T, Zhang D, Zhang Y, Xu X, Zhou B, Fang L, et al. Blocking CD226 promotes allogeneic transplant immune tolerance and improves skin graft survival by increasing the frequency of regulatory $T$ cells in a murine model. Cell Physiol Biochem. 2018:45(6):2338-50. https://doi.org/10.1159/000488182.

30. Toutirais O, Cabillic F, Le Friec G, Salot S, Loyer P, Le Gallo M, et al. DNAX accessory molecule-1 (CD226) promotes human hepatocellular carcinoma cell lysis by Vgamma9Vdelta2 T cells. Eur J Immunol. 2009;39(5):1361-8. https://doi.org/10.1002/eji.200838409.

31. Jin HS, Ko M, Choi DS, Kim JH, Lee DH, Kang SH, et al. CD226(hi)CD8(+) T cells are a prerequisite for anti-TIGIT immunotherapy. Cancer Immunol Res. 2020;8(7):912-25. https://doi.org/10.1158/2326-6066.CIR-19-0877.

32. Zhang $\mathrm{Q}, \mathrm{Bi}$ J, Zheng $\mathrm{X}$, Chen $\mathrm{Y}$, Wang $\mathrm{H}$, Wu W, et al. Blockade of the checkpoint receptor TIGIT prevents NK cell exhaustion and elicits potent 
anti-tumor immunity. Nat Immunol. 2018;19(7):723-32. https://doi.org/10.1 038/s41590-018-0132-0.

33. Maas RJ, Hoogstad-van Evert JS, Van der Meer JM, Mekers V, Rezaeifard S, Korman AJ, et al. TIGIT blockade enhances functionality of peritoneal NK cells with altered expression of DNAM-1/TIGIT/CD96 checkpoint molecules in ovarian cancer. Oncoimmunology. 2020;9(1):1843247. https://doi.org/10.1 080/2162402X.2020.1843247.

34. Chauvin JM, Pagliano O, Fourcade J, Sun Z, Wang H, Sander C, et al. TIGIT and PD-1 impair tumor antigen-specific $C D 8^{+} \mathrm{T}$ cells in melanoma patients. J Clin Invest. 2015;125(5):2046-58. https://doi.org/10.1172/JCl80445.

35. He W, Zhang H, Han F, Chen X, Lin R, Wang W, et al. CD155T/TIGIT signaling regulates CD8(+) T-cell metabolism and promotes tumor progression in human gastric Cancer. Cancer Res. 2017;77(22):6375-88. https://doi.org/10.1158/0008-5472.CAN-17-0381.

36. Guillerey C, Harjunpää H, Carrié N, Kassem S, Teo T, Miles K, et al. TIGIT immune checkpoint blockade restores CD8(+) T-cell immunity against multiple myeloma. Blood. 2018;132(16):1689-94. https://doi.org/10.1182/ blood-2018-01-825265.

37. Minnie SA, Kuns RD, Gartlan KH, Zhang P, Wilkinson AN, Samson L, et al. Myeloma escape after stem cell transplantation is a consequence of T-cell exhaustion and is prevented by TIGIT blockade. Blood. 2018;132(16):167588. https://doi.org/10.1182/blood-2018-01-825240.

38. Wu L, Mao L, Liu JF, Chen L, Yu GT, Yang LL, et al. Blockade of TIGIT/CD155 signaling reverses T-cell exhaustion and enhances antitumor capability in head and neck squamous cell carcinoma. Cancer Immunol Res. 2019;7(10): 1700-13. https://doi.org/10.1158/2326-6066.CIR-18-0725.

39. Lozano E, Mena MP, Díaz T, Martin-Antonio B, León S, Rodríguez-Lobato LG, et al. Nectin-2 expression on malignant plasma cells is associated with better response to TIGIT blockade in multiple myeloma. Clin Cancer Res. 2020;26(17):4688-98. https://doi.org/10.1158/1078-0432.CCR-19-3673.

40. Preillon J, Cuende J, Rabolli V, Garnero L, Mercier M, Wald N, et al. Restoration of T-cell effector function, depletion of Tregs, and direct killing of tumor cells: the multiple mechanisms of action of a-TIGIT antagonist antibodies. Mol Cancer Ther. 2021;20(1):121-31. https://doi.org/10.1158/153 5-7163.MCT-20-0464.

41. Hung AL, Maxwell R, Theodros D, Belcaid Z, Mathios D, Luksik AS, et al. TIGIT and PD-1 dual checkpoint blockade enhances antitumor immunity and survival in GBM. Oncoimmunology. 2018;7:e1466769.

42. Chen F, Xu Y, Chen Y, Shan S. TIGIT enhances CD4(+) regulatory T-cell response and mediates immune suppression in a murine ovarian cancer model. Cancer Med. 2020;9(10):3584-91. https://doi.org/10.1002/cam4.2976.

43. Blake SJ, Stannard K, Liu J, Allen S, Yong MC, Mittal D, et al. Suppression of metastases using a new lymphocyte checkpoint target for Cancer immunotherapy. Cancer Discov. 2016;6(4):446-59. https://doi.org/10.1158/21 59-8290.CD-15-0944.

44. Sun $H$, Huang Q, Huang M, Wen H, Lin R, Zheng M, et al. Human CD96 correlates to natural killer cell exhaustion and predicts the prognosis of human hepatocellular carcinoma. Hepatology. 2019;70(1):168-83. https://doi. org/10.1002/hep.30347.

45. Roman Aguilera A, Lutzky VP, Mittal D, Li XY, Stannard K, Takeda K, et al. CD96 targeted antibodies need not block CD96-CD155 interactions to promote NK cell anti-metastatic activity. Oncoimmunology. 2018;7(5): e1424677. https://doi.org/10.1080/2162402X.2018.1424677.

46. Chiang EY, de Almeida PE, de Almeida Nagata DE, Bowles KH, Du X, Chitre AS, et al. CD96 functions as a co-stimulatory receptor to enhance CD8(+) T cell activation and effector responses. Eur J Immunol. 2020;50(6):891-902. https://doi.org/10.1002/eji.201948405.

47. Mittal D, Lepletier A, Madore J, Aguilera AR, Stannard K, Blake SJ, et al. CD96 is an immune checkpoint that regulates CD8(+) T-cell antitumor function. Cancer Immunol Res. 2019;7(4):559-71. https://doi.org/10.1158/2326-6066. CIR-18-0637.

48. Stanko K, Iwert C, Appelt C, Vogt K, Schumann J, Strunk FJ, et al. CD96 expression determines the inflammatory potential of IL-9-producing Th9 cells. Proc Natl Acad Sci U S A. 2018;115(13):E2940-e2949. https://doi.org/1 $0.1073 /$ pnas.1708329115.

49. Xu F, Sunderland A, Zhou Y, Schulick RD, Edil BH, Zhu Y. Blockade of CD112R and TIGIT signaling sensitizes human natural killer cell functions. Cancer Immunol Immunother. 2017;66(10):1367-75. https://doi.org/10.1007/ s00262-017-2031-x

50. Whelan S, Ophir E, Kotturi MF, Levy O, Ganguly S, Leung L, et al. PVRIG and PVRL2 are induced in Cancer and inhibit CD8(+) T-cell function. Cancer
Immunol Res. 2019;7(2):257-68. https://doi.org/10.1158/2326-6066.CIR-180442.

51. Tahara-Hanaoka S, Shibuya K, Kai H, Miyamoto A, Morikawa Y, Ohkochi N, et al. Tumor rejection by the poliovirus receptor family ligands of the DNAM-1 (CD226) receptor. Blood. 2006;107(4):1491-6. https://doi.org/10.11 82/blood-2005-04-1684.

52. Chan CJ, Martinet L, Gilfillan S, Souza-Fonseca-Guimaraes F, Chow MT, Town $L$, et al. The receptors CD96 and CD226 oppose each other in the regulation of natural killer cell functions. Nat Immunol. 2014;15(5):431-8. https://doi.org/10.1038/ni.2850.

53. Chan CJ, Andrews DM, McLaughlin NM, Yagita H, Gilfillan S, Colonna M, et al. DNAM-1/CD155 interactions promote cytokine and NK cell-mediated suppression of poorly immunogenic melanoma metastases. J Immunol. 2010;184(2):902-11. https://doi.org/10.4049/jimmunol.0903225.

54. Verhoeven DH, de Hooge AS, Mooiman EC, Santos SJ, ten Dam MM, Gelderblom H, et al. NK cells recognize and lyse Ewing sarcoma cells through NKG2D and DNAM-1 receptor dependent pathways. Mol Immunol. 2008;45(15):3917-25. https://doi.org/10.1016/j.molimm.2008.06.016.

55. Lakshmikanth T, Burke S, Ali TH, Kimpfler S, Ursini F, Ruggeri L, et al. NCRs and DNAM-1 mediate NK cell recognition and lysis of human and mouse melanoma cell lines in vitro and in vivo. J Clin Invest. 2009;119(5):1251-63. https://doi.org/10.1172/JCl36022.

56. Pende D, Spaggiari GM, Marcenaro S, Martini S, Rivera P, Capobianco A, et al. Analysis of the receptor-ligand interactions in the natural killermediated lysis of freshly isolated myeloid or lymphoblastic leukemias: evidence for the involvement of the poliovirus receptor (CD155) and Nectin-2 (CD112). Blood. 2005;105(5):2066-73. https://doi.org/10.1182/ blood-2004-09-3548.

57. Zhang Z, Su T, He L, Wang H, Ji G, Liu X, et al. Identification and functional analysis of ligands for natural killer cell activating receptors in colon carcinoma. Tohoku J Exp Med. 2012;226(1):59-68. https://doi.org/10.1620/ tjem.226.59.

58. Carlsten M, Björkström NK, Norell H, Bryceson Y, van Hall T, Baumann BC, et al. DNAX accessory molecule-1 mediated recognition of freshly isolated ovarian carcinoma by resting natural killer cells. Cancer Res. 2007;67(3): 1317-25. https://doi.org/10.1158/0008-5472.CAN-06-2264.

59. Platonova S, Cherfils-Vicini J, Damotte D, Crozet L, Vieillard V, Validire P, et al Profound coordinated alterations of intratumoral NK cell phenotype and function in lung carcinoma. Cancer Res. 2011;71(16):5412-22. https://doi. org/10.1158/0008-5472.CAN-10-4179.

60. Iguchi-Manaka A, Okumura G, Ichioka E, Kiyomatsu H, Ikeda T, Bando H, et al. High expression of soluble CD155 in estrogen receptor-negative breast cancer. Breast Cancer. 2020;27(1):92-9. https://doi.org/10.1007/s122 82-019-00999-8.

61. Morgado S, Sanchez-Correa B, Casado JG, Duran E, Gayoso I, Labella F, et al NK cell recognition and killing of melanoma cells is controlled by multiple activating receptor-ligand interactions. J Innate Immun. 2011;3(4):365-73. https://doi.org/10.1159/000328505.

62. Hou S, Zheng X, Wei H, Tian Z, Sun R. Recombinant soluble CD226 protein directly inhibits cancer cell proliferation in vitro. Int Immunopharmacol. 2014;19(1):119-26. https://doi.org/10.1016/j.intimp.2014.01.012.

63. Yu X, Harden K, Gonzalez LC, Francesco M, Chiang E, Irving B, et al. The surface protein TIGIT suppresses T cell activation by promoting the generation of mature immunoregulatory dendritic cells. Nat Immunol. 2009; 10(1):48-57. https://doi.org/10.1038/ni.1674.

64. Stanietsky N, Simic H, Arapovic J, Toporik A, Levy O, Novik A, et al. The interaction of TIGIT with PVR and PVRL2 inhibits human NK cell cytotoxicity. Proc Natl Acad Sci U S A. 2009;106(42):17858-63. https://doi.org/10.1073/ pnas.0903474106.

65. Levin SD, Taft DW, Brandt CS, Bucher C, Howard ED, Chadwick EM, et al. Vstm3 is a member of the CD28 family and an important modulator of Tcell function. Eur J Immunol. 2011;41(4):902-15. https://doi.org/10.1002/eji.2 01041136.

66. Wu H, Chen Y, Liu H, Xu LL, Teuscher P, Wang S, et al. Follicular regulatory T cells repress cytokine production by follicular helper $T$ cells and optimize IgG responses in mice. Eur J Immunol. 2016;46(5):1152-61. https://doi.org/1 0.1002/eji.201546094.

67. Boles KS, Vermi W, Facchetti F, Fuchs A, Wilson TJ, Diacovo TG, et al. A novel molecular interaction for the adhesion of follicular CD4 T cells to follicular DC. Eur J Immunol. 2009;39(3):695-703. https://doi.org/10.1002/eji.2 00839116. 
68. Takai Y, Irie K, Shimizu K, Sakisaka T, Ikeda W. Nectins and nectin-like molecules: roles in cell adhesion, migration, and polarization. Cancer Sci. 2003;94(8):655-67. https://doi.org/10.1111/j.1349-7006.2003.tb01499.x.

69. Nishiwada S, Sho M, Yasuda S, Shimada K, Yamato I, Akahori T, et al. Nectin4 expression contributes to tumor proliferation, angiogenesis and patient prognosis in human pancreatic cancer. J Exp Clin Cancer Res. 2015;34(1):30. https://doi.org/10.1186/s13046-015-0144-7.

70. Reches A, Ophir Y, Stein N, Kol I, Isaacson B, Charpak Amikam Y, et al. Nectin4 is a novel TIGIT ligand which combines checkpoint inhibition and tumor specificity. J Immunother Cancer. 2020;8(1):e000266. https://doi.org/1 0.1136/jitc-2019-000266.

71. Liu S, Zhang H, Li M, Hu D, Li C, Ge B, et al. Recruitment of Grb2 and SHIP1 by the ITT-like motif of TIGIT suppresses granule polarization and cytotoxicity of NK cells. Cell Death Differ. 2013;20(3):456-64. https://doi.org/1 0.1038/cdd.2012.141.

72. Li M, Xia P, Du Y, Liu S, Huang G, Chen J, et al. T-cell immunoglobulin and ITIM domain (TIGIT) receptor/poliovirus receptor (PVR) ligand engagement suppresses interferon- $\gamma$ production of natural killer cells via $\beta$-arrestin 2 mediated negative signaling. J Biol Chem. 2014;289(25):17647-57. https:// doi.org/10.1074/jbc.M114.572420.

73. Zhang $C$, Wang $Y$, Xun X, Wang S, Xiang X, Hu S, et al. TIGIT can exert immunosuppressive effects on CD8+ T cells by the CD155/TIGIT signaling pathway for hepatocellular carcinoma in vitro. J Immunother. 2020;43(8): 236-43. https://doi.org/10.1097/CJ.0000000000000330.

74. Kurtulus S, Sakuishi K, Ngiow SF, Joller N, Tan DJ, Teng MW, et al. TIGIT predominantly regulates the immune response via regulatory $T$ cells. J Clin Invest. 2015;125(11):4053-62. https://doi.org/10.1172/JCl81187

75. Joller N, Lozano E, Burkett PR, Patel B, Xiao S, Zhu C, et al. Treg cells expressing the coinhibitory molecule TIGIT selectively inhibit proinflammatory Th1 and Th17 cell responses. Immunity. 2014;40(4):569-81. https://doi.org/10.1016/j.immuni.2014.02.012.

76. De Vlaeminck Y, González-Rascón A, Goyvaerts C, Breckpot K. Cancerassociated myeloid regulatory cells. Front Immunol. 2016;7:113.

77. Deuss FA, Watson GM, Fu Z, Rossjohn J, Berry R. Structural Basis for CD96 Immune Receptor Recognition of Nectin-like Protein-5, CD155. Structure. 2019;27:219-28 e213.

78. Lozano E, Dominguez-Villar M, Kuchroo V, Hafler DA. The TIGIT/CD226 axis regulates human T cell function. J Immunol. 2012;188(8):3869-75. https:// doi.org/10.4049/jimmunol.1103627.

79. Johnston RJ, Comps-Agrar L, Hackney J, Yu X, Huseni M, Yang Y, et al. The immunoreceptor TIGIT regulates antitumor and antiviral CD8(+) T cell effector function. Cancer Cell. 2014;26(6):923-37. https://doi.org/10.1016/j. ccell.2014.10.018.

80. Stanietsky N, Rovis TL, Glasner A, Seidel E, Tsukerman P, Yamin R, et al. Mouse TIGIT inhibits NK-cell cytotoxicity upon interaction with PVR. Eur J Immunol. 2013;43(8):2138-50. https://doi.org/10.1002/eji.201243072.

81. Wang F, Hou H, Wu S, Tang Q, Liu W, Huang M, et al. TIGIT expression levels on human NK cells correlate with functional heterogeneity among healthy individuals. Eur J Immunol. 2015;45(10):2886-97. https://doi.org/10.1002/eji.2 01545480 .

82. Sarhan D, Cichocki F, Zhang B, Yingst A, Spellman SR, Cooley S, et al. Adaptive NK cells with low TIGIT expression are inherently resistant to myeloid-derived suppressor cells. Cancer Res. 2016;76(19):5696-706. https:// doi.org/10.1158/0008-5472.CAN-16-0839.

83. Kong Y, Zhu L, Schell TD, Zhang J, Claxton DF, Ehmann WC, et al. T-cell immunoglobulin and ITIM domain (TIGIT) associates with CD8+ T-cell exhaustion and poor clinical outcome in AML patients. Clin Cancer Res. 2016;22(12):3057-66. https://doi.org/10.1158/1078-0432.CCR-15-2626.

84. Wang PL, O'Farrell S, Clayberger C, Krensky AM. Identification and molecular cloning of tactile. A novel human T cell activation antigen that is a member of the Ig gene superfamily. J Immunol. 1992;148:2600-8.

85. McVicar DW, Burshtyn DN. Intracellular signaling by the killer immunoglobulin-like receptors and Ly49. Sci STKE. 2001;2001:re1.

86. Meyer D, Seth S, Albrecht J, Maier MK, du Pasquier L, Ravens I, et al. CD96 interaction with CD155 via its first lg-like domain is modulated by alternative splicing or mutations in distal Ig-like domains. J Biol Chem. 2009; 284(4):2235-44. https://doi.org/10.1074/jbc.M807698200.

87. Garg S, Madkaikar M, Ghosh K. Investigating cell surface markers on normal hematopoietic stem cells in three different niche conditions. Int J Stem Cells. 2013;6(2):129-33. https://doi.org/10.15283/ijsc.2013.6.2.129.
88. Seth S, Maier MK, Qiu Q, Ravens I, Kremmer E, Förster R, et al. The murine pan T cell marker CD96 is an adhesion receptor for CD155 and nectin-1. Biochem Biophys Res Commun. 2007;364(4):959-65. https://doi.org/10.1016/ j.bbrc.2007.10.102.

89. Fuchs A, Cella M, Giurisato E, Shaw AS, Colonna M. Cutting edge: CD96 (tactile) promotes NK cell-target cell adhesion by interacting with the poliovirus receptor (CD155). J Immunol. 2004;172(7):3994-8. https://doi. org/10.4049/jimmunol.172.7.3994.

90. Lenac Rovis T, Kucan Brlic P, Kaynan N, Juranic Lisnic V, Brizic I, Jordan S, et al. Inflammatory monocytes and NK cells play a crucial role in DNAM-1dependent control of cytomegalovirus infection. J Exp Med. 2016;213(9): 1835-50. https://doi.org/10.1084/jem.20151899.

91. Fuchs A, Cella M, Kondo T, Colonna M. Paradoxic inhibition of human natural interferon-producing cells by the activating receptor NKp44. Blood. 2005:106(6):2076-82. https://doi.org/10.1182/blood-2004-12-4802.

92. Jang IK, Zhang J, Chiang YJ, Kole HK, Cronshaw DG, Zou Y, et al. Grb2 functions at the top of the T-cell antigen receptor-induced tyrosine kinase cascade to control thymic selection. Proc Natl Acad Sci U S A. 2010;107(23): 10620-5. https://doi.org/10.1073/pnas.0905039107.

93. Wange RL, Samelson LE. Complex complexes: signaling at the TCR. Immunity. 1996;5(3):197-205. https://doi.org/10.1016/S1074-7613(00)80315-5

94. Adachi K, Davis MM. T-cell receptor ligation induces distinct signaling pathways in naive vs. antigen-experienced T cells. Proc Natl Acad Sci U S A. 2011;108(4):1549-54. https://doi.org/10.1073/pnas.1017340108.

95. Boomer JS, Green JM. An enigmatic tail of CD28 signaling. Cold Spring Harb Perspect Biol. 2010;2:a002436.

96. Peng YP, Xi CH, Zhu Y, Yin LD, Wei JS, Zhang JJ, et al. Altered expression of CD226 and CD96 on natural killer cells in patients with pancreatic cancer. Oncotarget. 2016;7(41):66586-94. https://doi.org/10.18632/oncotarget.11953.

97. Zhu Y, Paniccia A, Schulick AC, Chen W, Koenig MR, Byers JT, et al. Identification of CD112R as a novel checkpoint for human T cells. J Exp Med. 2016;213(2):167-76. https://doi.org/10.1084/jem.20150785.

98. Billadeau DD, Leibson PJ. ITAMs versus ITIMs: striking a balance during cell regulation. J Clin Invest. 2002;109(2):161-8. https://doi.org/10.1172/JCI0214 843.

\section{Publisher's Note}

Springer Nature remains neutral with regard to jurisdictional claims in published maps and institutional affiliations.

Ready to submit your research? Choose BMC and benefit from:

- fast, convenient online submission

- thorough peer review by experienced researchers in your field

- rapid publication on acceptance

- support for research data, including large and complex data types

- gold Open Access which fosters wider collaboration and increased citations

- maximum visibility for your research: over $100 \mathrm{M}$ website views per year

At BMC, research is always in progress.

Learn more biomedcentral.com/submissions 